\title{
Effects of Organic Amendments Produced from Agro-Wastes on Sandy Soil Properties and Black Pepper Morpho-Physiology and Yield
}

\author{
Kevin Muyang Tawie Sulok ${ }^{1}\left(\mathbb{D}\right.$, Osumanu Haruna Ahmed ${ }^{2,3,4}{ }^{(D)}$, Choy Yuen Khew ${ }^{1}$ (D), \\ Jarroop Augustine Mercer Zehnder ${ }^{1}$, Pei Sing Lai ${ }^{1}$, Mohamadu Boyie Jalloh ${ }^{5, * \mathbb{D}}$, Adiza Alhassan Musah ${ }^{6} \mathbb{D}$, \\ Azwan Awang ${ }^{5}$ and Arifin Abdu ${ }^{7}$
}

check for updates

Citation: Sulok, K.M.T.; Ahmed, O.H.; Khew, C.Y.; Zehnder, J.A.M.; Lai, P.S.; Jalloh, M.B.; Musah, A.A.; Awang, A.; Abdu, A. Effects of Organic Amendments Produced from Agro-Wastes on Sandy Soil Properties and Black Pepper Morpho-Physiology and Yield. Agronomy 2021, 11, 1738. https://doi.org/10.3390/agronomy 11091738

Academic Editors: San-Lang Wang, Anh Dzung Nguyen, Van Bon Nguyen and Chien Thang Doan

Received: 18 August 2021

Accepted: 27 August 2021

Published: 29 August 2021

Publisher's Note: MDPI stays neutral with regard to jurisdictional claims in published maps and institutional affiliations.

Copyright: (c) 2021 by the authors. Licensee MDPI, Basel, Switzerland. This article is an open access article distributed under the terms and conditions of the Creative Commons Attribution (CC BY) license (https:/ / creativecommons.org/licenses/by/ $4.0 /)$.
1 Research and Development Division, Malaysian Pepper Board, Kuching 93916, Malaysia; kevinmuyang@mpb.gov.my (K.M.T.S.); cykhew@mpb.gov.my (C.Y.K.); zehnder@mpb.gov.my (J.A.M.Z.); laips@mpb.gov.my (P.S.L.)

2 Department of Forestry Science, Faculty of Agricultural Science and Forestry, Universiti Putra Malaysia Bintulu Campus, Bintulu 97008, Malaysia; osumanu@upm.edu.my

3 Institut Ekosains Borneo, Universiti Putra Malaysia Bintulu Campus, Bintulu 97008, Malaysia

4 Institute of Tropical Agriculture and Food Security (ITAFoS), Universiti Putra Malaysia, Serdang 43400, Malaysia

5 Crop Production Programme, Faculty of Sustainable Agriculture, Universiti Malaysia Sabah, Sandakan Branch, Locked Bag No. 3, Sandakan 90509, Malaysia; azwang@ums.edu.my

6 Faculty of Business Management and Professional Studies, Management \& Science University, University Drive, Off Persiaran Olahraga, Section 13, Shah Alam 40100, Malaysia; adiza_alhassan@msu.edu.my

7 Faculty of Forestry and Environment, Universiti Putra Malaysia, Serdang 43400, Malaysia; arifinabdu@upm.edu.my

* Correspondence: mbjalloh@ums.edu.my; Tel.: +60-12-9321097

Abstract: Sandy-textured soil infertility poses a problem for sustainable crop cultivation. This problem is usually dealt with by the addition of chemical fertilizers, which are expensive and can cause serious environmental issues if not managed well. A better alternative to improve and manage sandy soil infertility is the use of organic amendments produced from agro-wastes. This two (2)-year field study was conducted in a sandy-textured soil grown with black pepper to evaluate mainly the effects of chemical fertilizer, fermented plant and fruit juices, compost, and biochar on soil properties and morpho-physiological characteristics and yield of black pepper. Generally, the results indicated that the combination of fermented fruit juice, compost, and biochar was comparable to and in some cases better than chemical fertilizer in terms of soil physical, chemical, and biological properties as well as crop performance. These findings were even more pronounced in the second year of measurements. There were strong positive relationships between soil $\mathrm{N}$ and pepper leaf chlorophyll content and between soil microbes and soil respiration. The findings showed that these soil amendments produced from agro-wastes are a good alternative to the use of chemical fertilizers on sandy soils to improve soil fertility and productivity and the yield of black pepper sustainably.

Keywords: agricultural wastes; organic agriculture; soil health; crop productivity; black pepper

\section{Introduction}

Predominantly sandy-textured soils are not considered very suitable for agricultural crop production, especially for crops that are easily stressed by soils with poor waterholding capacities [1,2]. Sandy-textured soils are fragile and require significant resources for sustainable management when used for crop agriculture. They are poor in nutrients, have low cation exchange capacity (CEC), poor water-holding capacity, high bulk density, poor nutrient retention, lack structure, are low in organic matter content, and have minimal 
microbial life. These characteristics pose a challenge for sustainable crop production, especially soil fertility improvement, which is an important aspect of healthy soils [3-7].

The application of chemical fertilizers or organic amendments to such soil are options available for ameliorating the poor fertility status of sandy soils [8-10]. However, the problem with continuous and excessive use of inorganic or chemical fertilizers is the danger they pose to the environment, especially to our rivers and water sources if these fertilizers leach or runoff, which is often the case. This happens because many inorganic or chemical fertilizers are readily soluble or volatile and are easily leached through the soil, washed over land surface, or changed into forms that escape into the atmosphere [11-15]. Chemical fertilizers have also been shown to degrade soils with significant deleterious effects on soil life [16-19].

To overcome this problem, the use of organic fertilizers or amendments produced from agricultural wastes has been advocated, as they are less of a danger compared with chemical fertilizers due to their slow release characteristics, less losses to the environment if managed well, and improvements in soil life. Various studies have shown that organic amendments, when applied to sandy and other textured soils, significantly improve soil fertility, crop performance, and yields [7,8,16,20,21].

Black pepper (Piper nigrum L.), which will simply be referred to as pepper in the rest of this paper, is a significant economic crop to smallholders in Sarawak, Malaysia, and there are extensive sandy-textured soil areas grown with this crop. Smallholders are usually disadvantaged in their capability to purchase fertilizer and other inputs for their crops, which has caused declining pepper yields to farmers and even abandoning of farms [22]. The use of organic fertilizers which they can readily produce using the agricultural waste products from their farms is worth trying for the possible benefits to their farm sustainability.

It is against this background that chemical NPK fertilizer and organic amendments produced from farm wastes were used in this field study to evaluate mainly their effects on: (i) sandy soil properties and (ii) morpho-physiological characteristics and yield of pepper.

\section{Materials and Methods}

\subsection{Experimental Site}

This 30-month study was carried out at Kampung Serayan Hilir, Sematan, Sarawak, Malaysia, in a four-year-old black pepper (Piper nigrum var. Kuching) farm sized approximately 0.5 hectares. The farm had uniform and healthy fruit-bearing mature pepper vines aged four years. The soil at the farm belongs to Miri Series [23], which is a sandy, isohyperthermic, strongly cemented Typic Haplorthod. Due to its sandy nature and very poor fertility status, soils of the Miri Series are considered to be not suitable for agriculture and best left under their natural vegetation [24].

\subsection{Experimental Design and Treatments}

The experiment was conducted using a randomized complete block design (RCBD) with five treatments, each replicated three times, resulting in a total of 15 plots each having 5 vines. The treatments used in this study were: (i) T1-NPK as a control, (ii) T2-Fermented Plant Juice (FPJ), (iii) T3-Fermented Plant Juice incorporated with biochar and compost (FPJBC), (iv) T4-Fermented Fruit Juice (FFJ), and (v) T5-Fermented Fruit Juice incorporated with biochar and compost (FFJBC). The details of the treatments are shown in Table 1. The application rates for T2, T3, T4, and T5 were adapted from Zamara and Calub [25] and the Malaysian Pepper Board [26]. The FPJ and FFJ were prepared monthly to ensure that only fresh batches of fermented juices were used. From the onset of the experiment, FPJ and FFJ were applied once a month. The composition and the chemical and biological characteristics of the fermented juices, biochar, and compost were reported in [27], wherein the results showed that the fermented juices contain important microbes that can solubilize $\mathrm{P}$ and $\mathrm{K}$ for crop use. The plant waste compost contained far higher amounts of N, P, and K compared with the fermented juices and biochar. The control 
treatment application, which was a compound chemical fertilizer (NPK-12:12:17), was performed based on the recommendation of $[26,28]$ and the details are shown in Table 2.

Table 1. Description of treatments, composition, and rates of application.

\begin{tabular}{|c|c|c|c|}
\hline Treatment & Description & Composition & Rate of Application \\
\hline $\begin{array}{c}\mathrm{T} 1 \\
\text { (NPK) }\end{array}$ & Control & NPK 12:12:17 & Standard recommended rate as shown in Table 2 \\
\hline $\begin{array}{c}\mathrm{T} 2 \\
(\mathrm{FPJ})\end{array}$ & Fermented Plant Juice (FPJ) & $\begin{array}{l}1 \mathrm{~kg} \text { of water spinach, Chinese } \\
\text { mustard, black pepper leaves, } \\
\text { tapioca leaves, } 1 \mathrm{~kg} \text { molasses }\end{array}$ & $\begin{array}{c}200 \mathrm{~mL} \text { of FPJ in } 16 \text { litres of water per month per } \\
100 \text { vines }\end{array}$ \\
\hline $\begin{array}{c}\mathrm{T} 3 \\
(\mathrm{FPJBC})\end{array}$ & $\begin{array}{l}\text { Fermented Plant Juice } \\
\text { incorporated with biochar and } \\
\text { compost (FPJBC) }\end{array}$ & $\begin{array}{l}\text { FPJ, palm kernel shell biochar, } \\
\text { and plant waste compost }\end{array}$ & $\begin{array}{c}200 \mathrm{~mL} \text { of FPJ in } 16 \text { litres of water per month per } \\
100 \text { vines. } 1 \mathrm{~kg} \text { of biochar applied per vine per } \\
\text { year. } 3.5 \mathrm{~kg} \text { compost applied per vine every } 3 \\
\text { months }\end{array}$ \\
\hline $\begin{array}{c}\mathrm{T} 4 \\
(\mathrm{FFJ})\end{array}$ & Fermented Fruit Juice (FFJ) & $\begin{array}{l}1 \mathrm{~kg} \text { banana, papaya, } \\
\text { pumpkin, and pepper berries, } \\
1 \mathrm{~kg} \text { molasses }\end{array}$ & $\begin{array}{l}200 \mathrm{~mL} \text { of FFJ in } 16 \text { litres of water per month per } \\
100 \text { vines }\end{array}$ \\
\hline $\begin{array}{c}\mathrm{T} 5 \\
(\mathrm{FFJBC})\end{array}$ & $\begin{array}{l}\text { Fermented Fruit Juice } \\
\text { incorporated with biochar and } \\
\text { compost (FFJBC) }\end{array}$ & $\begin{array}{l}\text { FFJ, palm kernel shell biochar } \\
\text { and plant waste compost }\end{array}$ & $\begin{array}{c}200 \mathrm{~mL} \text { of FFJ in } 16 \text { litres of water per month per } \\
100 \text { vines. } 1 \mathrm{~kg} \text { of biochar applied per vine per } \\
\text { year. } 3.5 \mathrm{~kg} \text { compost applied per vine every } \\
3 \text { months }\end{array}$ \\
\hline
\end{tabular}

Table 2. Chemical fertilizer application rates for mature pepper vines.

\begin{tabular}{ccc}
\hline Month after Planting & Compound Chemical Fertilizer & Quantity per Vine (g) \\
\hline September & $12: 12: 17: 2+\mathrm{TE} *$ & 500 \\
October & $12: 12: 17: 2+\mathrm{TE}$ & 500 \\
November & $12: 12: 17: 2+\mathrm{TE}$ & 250 \\
December & $12: 12: 17: 2+\mathrm{TE}$ & 250 \\
\hline \multicolumn{2}{r}{ TE $=$ Trace Elements. }
\end{tabular}

\subsection{Soil Physical, Chemical and Biological Analysis}

Soil samples were obtained from the plots for two assessment years (2017 and 2018) which were used for physical, chemical, and biological characterization using known laboratory analytical procedures. For the physical analysis, soil bulk density, porosity, and texture were determined using the methods described in [29]. For the chemical analysis, soil $\mathrm{pH}$ in $1 \mathrm{M} \mathrm{KCl}$ and $\mathrm{H}_{2} \mathrm{O}$ were determined using soil samples with a $\mathrm{KCl}$ and water $(w / v)$ ratio of 1:2.5 respectively [29]. The electrical conductivity was measured using a conductance meter (WS SMEC 300, Spectrum Technologies, Chicago, IL, USA) that was standardized with 0.01 and $0.1 \mathrm{M} \mathrm{KCl}$. The soil cation exchange capacity (CEC) was determined using the ammonium acetate (leaching) method [30]. Soil organic carbon was determined using loss on ignition method [29]. Soil total $\mathrm{N}$ was determined using the micro-Kjeldahl method [31]. Soil available P was determined using Bray I method [29]. The double acid method [29] was used to extract the exchangeable $\mathrm{K}, \mathrm{Ca}, \mathrm{Mg}$, and $\mathrm{Na}$ in soil followed by Atomic Absorption Spectrophotometry (AAS AA-7700, Shimadzu Corporation, Kyoto, Japan) measurements. For the biological analysis, total microorganisms count and yeast-mold were determined using the dilution method [29].

\subsection{Soil Respiration Measurements}

To measure carbon mineralization by microorganisms or soil respiration, a LI6400-09 soil chamber connected to an LI-6400 portable photosynthesis system (LI-COR Inc., Lincoln, NE, USA), following the method of DiCristina and Germino [32]. Collars with a height of $4.4 \mathrm{~cm}$ and a diameter of $11 \mathrm{~cm}$ were inserted into the soil for measuring soil respiration. 
Concurrently, soil temperature readings were recorded by inserting a thermocouple probe into the soil at a depth of four $\mathrm{cm}$. Morning soil respiration and soil temperature were measured at the end of the harvesting period.

\subsection{Pepper Plant Physiological, Morphological and Yield Measurements}

Before the annual harvest of the pepper berries, measurement of pepper net photosynthesis rate $(A)$, leaf stomatal conductance rate $(g s)$, transpiration rate $(E)$, normalized difference vegetation index (NDVI), foliar chlorophyll concentration, and the length of fruit spike and leaf area index (LAI) was performed. Fresh berry yield was recorded during the harvesting months.

\subsubsection{Pepper Leaves Gas Exchange Rates Measurements}

Gas exchange measurements were carried out on newly matured leaves with the same orientation and same layer in the crown (middle bottom). Measurements of net photosynthesis on area basis $(\mathrm{A})\left(\mu \mathrm{mol} \mathrm{CO} \mathrm{m}^{-2} \mathrm{~s}^{-1}\right)$, leaf stomatal conductance $(\mathrm{gs})(\mathrm{mol}$ $\left.\mathrm{H}_{2} \mathrm{O} \mathrm{m}^{-2} \mathrm{~s}^{-1}\right)$, and transpiration rate (E) $\left(\mathrm{mmol} \mathrm{H}_{2} \mathrm{O} \mathrm{m}^{-2} \mathrm{~s}^{-1}\right)$ of five different leaves per treatment were monitored using a LICOR 6400 XT (LICOR Inc., Lincoln, NE, USA) infrared gas analyzer (IRGA). Light intensity (Photosynthetically active radiation, PAR) within the sampling chamber was set at $1500 \mu \mathrm{mol} \mathrm{m}^{-2} \mathrm{~s}^{-1}$ using an LI-6400-02B LED light source (LI-COR). Carbon dioxide flow into the chamber was maintained at a concentration of $400 \mu \mathrm{mol} \mathrm{mol}{ }^{-1}$ using a LI-6400-01 $\mathrm{CO}_{2}$ mixer (LI-COR). The humidity flow into the chamber was fixed at $500 \mu \mathrm{mol} \mathrm{s}^{-1}$, and desiccant mid-range between scrub and bypass. Statistical assessment was carried out on gas exchange parameters at between 1100 to $1300 \mathrm{~h}$, which was the diurnal period when photosynthetic rates would be maximal [32].

\subsubsection{Pepper Foliar Chlorophyll Concentration and NDVI}

Foliar chlorophyll concentration was determined using the MC-100 chlorophyll meter (Apogee Inst., Logan, UT, USA). The NDVI was recorded using an NDVI meter (CM1000, Spectrum, FieldScout, Aurora, IL, USA). Readings were recorded when newly matured leaves with the same orientation and same layer in the crown (middle bottom) were attached to the tree.

\subsubsection{Average Length of Fruit Spike Measurements}

Average length of fruit spike was measured on 20 selected fruit spikes per vine, using a digital Vernier caliper (CD-15CX, Mitutoyo, Kawasaki, Japan) in millimeters up to two decimal places.

\subsubsection{Leaf Area Index Measurements}

The leaf area index (LAI) of the pepper vines was measured non-destructively and rapidly at a given time by using the LAI-2200 Plant Canopy Analyzer (LI-COR Inc., Lincoln, NE, USA). This indirect estimation of LAI was based on the difference in light interception above and below the canopy of the pepper plant [33]. Subsequently, the LAI-2200 PCA computed the LAI for a canopy from the ratios of a reference reading above the canopy and the readings beneath the canopy. Each LAI value was obtained by analyzing the estimates of LAI from a set of five randomly allocated sampling positions under the canopy. The measurements were conducted under cloudy conditions or during the early morning when sky brightness was uniform.

\subsubsection{Fresh Berry Yield Determination}

Fresh berries yields were obtained from two harvesting seasons, within the months of March to September, in 2017 and 2018. The average yield was calculated based on the weight of fresh berries per kilogram per vine per year. 


\subsection{Statistical Analysis}

The data were analyzed using one-way analysis of variance (ANOVA) with the SPSS software (version 15). Tukey's Honest Significance Difference (HSD) Test, at $\alpha=0.05$ level of significance, was performed to compare the treatment means. The relationships between soil respiration and soil microorganism count (bacteria, actinomycetes, and fungi) were obtained using regression analysis. The relationships between pepper foliar chlorophyll and soil total N, pepper NDVI and soil total N, and pepper photosynthesis rate and soil total $\mathrm{N}$ were also obtained using regression analysis.

\section{Results}

\subsection{Selected Physicochemical Properties of Miri Series}

Selected physical and chemical properties of the Miri series (Typic Haplorthods) are presented in Table 3. The physical properties indicate that it is a well-drained soil. Its chemical properties indicate that it is less fertile and this is consistent with the Soil Survey Staff report [23].

Table 3. Selected physical and chemical properties of Miri series (Typic Haplorthods).

\begin{tabular}{cc}
\hline Property & Value Obtained \\
\hline BD $\left(\mathrm{g} / \mathrm{cm}^{3}\right)$ & 1.40 \\
Porosity $(\%)$ & 39.20 \\
Sand $(\%)$ & 76 \\
Silt $(\%)$ & 9 \\
Clay $(\%)$ & 15 \\
Soil texture & Sandy loam \\
pH (water) & 4.08 \\
EC $(\mathrm{dS} / \mathrm{m})$ & 2.3 \\
CEC $(\mathrm{cmol}(+) / \mathrm{kg})$ & 8.06 \\
TOC $(\%)$ & 1.32 \\
Total N $(\%)$ & 0.14 \\
C $/ \mathrm{N} \mathrm{Ratio}$ & 9.43 \\
Available P $(\mathrm{mg} / \mathrm{kg})$ & 144 \\
Exchangeable K $(\mathrm{cmol}(+) / \mathrm{kg})$ & 0.13 \\
Exchangeable Ca $(\mathrm{cmol}(+) / \mathrm{kg})$ & 0.57 \\
Exchangeable Na $(\mathrm{cmol}(+) / \mathrm{kg})$ & 0.32 \\
Exchangeable $\mathrm{Mg}(\mathrm{cmol}(+) / \mathrm{kg})$ & 0.19
\end{tabular}

Note: $\mathrm{BD}=$ Bulk density, $\mathrm{EC}=$ Electrical conductivity, $\mathrm{CEC}=$ Cation Exchange Capacity, TOC = Total Organic Carbon, $\mathrm{N}$ = Nitrogen, $\mathrm{P}=$ Phosphorus, $\mathrm{K}=$ Potassium, $\mathrm{Ca}=$ Calcium, $\mathrm{Na}=$ Sodium, $\mathrm{Mg}=$ Magnesium.

Paramananthan [24] stated that because of the sand content and drainage problems (excessive) of the Miri series, most of the areas that are occupied by this soil series have very poor kerangas forest or secondary vegetation. Due to its high sand content and very poor fertility status, the Miri series is not suitable for agriculture and is best left for natural vegetation. Despite the high available P content of this soil as shown in Table 3, the fertility of this soil is considered poor due to low CEC, TOC, total N and exchangeable $\mathrm{K}, \mathrm{Ca}$, and $\mathrm{Mg}$. The low $\mathrm{pH}$ of this can compound this problem by making nutrients unavailable for plant uptake. The proportions of sand, silt, and clay of the Miri series are $76 \%, 9 \%$, and $15 \%$, respectively, which is a sandy loam soil.

\subsection{Effects of Treatments on Soil Physical and Chemical Properties}

The effects of different amendments on the sandy soil's bulk density and porosity in 2017 and 2018 are presented in Table 4. The results indicate that with the exception of the the soil treated with NPK fertilizer, soil bulk density was low in 2017. In 2018, the fermented juices with compost and biochar (FPJBC and FFFJBC) treatments showed the lowest bulk densities compared with the fermented juices-only treatments (FPJ and FFJ) and chemical fertilizer (NPK). Results for soil porosity were similar to those of the soil bulk 
density in which FPJBC and FFJBC showed higher soil porosity compared with FPJ, FFJ, and NPK.

Table 4. Treatments effects on soil bulk density, porosity, $\mathrm{pH}$, electrical conductivity (EC), and Cation Exchange Capacity (CEC) for two years of observation.

\begin{tabular}{|c|c|c|c|c|c|c|c|}
\hline Treatment & Year & $\begin{array}{l}\text { Bulk Density } \\
\quad\left(\mathrm{g} \mathrm{cm}^{-3}\right)\end{array}$ & Porosity (\%) & $\mathrm{pH}_{\text {water }}$ & $\mathrm{pH}_{\mathrm{KCl}}$ & $\begin{array}{c}\mathrm{EC} \\
(\mathrm{dS} / \mathrm{m})\end{array}$ & $\begin{array}{c}\text { CEC } \\
\left(\mathrm{cmol}_{(+)} / \mathrm{kg}\right)\end{array}$ \\
\hline NPK & & $\begin{array}{l}1.38 \pm \\
0.03^{a}\end{array}$ & $\begin{array}{c}52.08 \pm \\
2.81^{\mathrm{a}}\end{array}$ & $\begin{array}{l}4.06 \pm \\
0.23^{c}\end{array}$ & $\begin{array}{l}3.58 \pm \\
0.40^{\mathrm{c}}\end{array}$ & $\begin{array}{c}2.30 \pm \\
0.38^{a}\end{array}$ & $\begin{array}{c}11.69 \pm \\
0.39^{c}\end{array}$ \\
\hline FPJ & 2017 & $\begin{array}{l}1.33 \pm \\
0.07 \mathrm{ab}\end{array}$ & $\begin{array}{c}50.19 \pm \\
1.21 \mathrm{~b}\end{array}$ & $\begin{array}{l}4.59 \pm \\
0.16^{b}\end{array}$ & $\begin{array}{l}4.02 \pm \\
0.28^{b}\end{array}$ & $\begin{array}{l}1.40 \pm \\
0.22 \mathrm{~b}\end{array}$ & $\begin{array}{r}11.99 \pm \\
0.42^{\mathrm{c}}\end{array}$ \\
\hline FPJBC & & $\begin{array}{l}1.32 \pm \\
0.06^{b}\end{array}$ & $\begin{array}{c}49.81 \pm \\
1.53^{\mathrm{b}}\end{array}$ & $\begin{array}{l}4.50 \pm \\
0.18^{b}\end{array}$ & $\begin{array}{l}4.18 \pm \\
0.27^{b}\end{array}$ & $\begin{array}{l}1.30 \pm \\
0.27^{b}\end{array}$ & $\begin{array}{c}12.77 \pm \\
0.31^{\mathrm{b}}\end{array}$ \\
\hline FFJ & & $\begin{array}{l}1.33 \pm \\
0.04^{b}\end{array}$ & $\begin{array}{c}49.62 \pm \\
0.85^{b}\end{array}$ & $\begin{array}{l}4.55 \pm \\
0.17^{b}\end{array}$ & $\begin{array}{l}4.16 \pm \\
0.19^{b}\end{array}$ & $\begin{array}{l}1.50 \pm \\
0.24^{b}\end{array}$ & $\begin{array}{r}11.77 \pm \\
0.49^{\mathrm{c}}\end{array}$ \\
\hline FFJBC & & $\begin{array}{l}1.21 \pm \\
0.05^{\mathrm{b}} \\
\end{array}$ & $\begin{array}{c}50.11 \pm \\
0.85^{b}\end{array}$ & $\begin{array}{l}5.08 \pm \\
0.24^{\mathrm{a}} \\
\end{array}$ & $\begin{array}{l}4.52 \pm \\
0.20^{a} \\
\end{array}$ & $\begin{array}{l}1.40 \pm \\
0.28^{\mathrm{b}} \\
\end{array}$ & $\begin{array}{c}15.26 \pm \\
0.47^{\mathrm{a}} \\
\end{array}$ \\
\hline NPK & & $\begin{array}{l}1.42^{ \pm} \\
0.05^{\mathrm{a}}\end{array}$ & $\begin{array}{c}46.41 \pm \\
1.86^{\mathrm{b}}\end{array}$ & $\begin{array}{l}4.03 \pm \\
0.24^{d}\end{array}$ & $\begin{array}{l}3.29 \pm \\
0.42^{d}\end{array}$ & $\begin{array}{c}2.71 \pm \\
0.25^{\mathrm{a}}\end{array}$ & $\begin{array}{r}10.71 \pm \\
0.99^{\mathrm{c}}\end{array}$ \\
\hline FPJ & 2018 & $\begin{array}{l}1.31 \pm \\
0.09^{a}\end{array}$ & $\begin{array}{c}50.41 \pm \\
3.53^{\mathrm{b}}\end{array}$ & $\begin{array}{l}4.64^{ \pm} \\
0.15^{c}\end{array}$ & $\begin{array}{l}3.80^{ \pm} \\
0.15^{\mathrm{c}}\end{array}$ & $\begin{array}{l}1.30 \pm \\
0.17^{b}\end{array}$ & $\begin{array}{c}11.73 \pm \\
0.65^{\mathrm{b}}\end{array}$ \\
\hline FPJBC & & $\begin{array}{l}1.13 \pm \\
0.19^{b}\end{array}$ & $\begin{array}{c}57.41 \pm \\
7.28^{\mathrm{a}}\end{array}$ & $\begin{array}{l}5.07 \pm \\
0.13^{b}\end{array}$ & $\begin{array}{l}4.10 \pm \\
0.06^{b}\end{array}$ & $\begin{array}{l}1.21 \pm \\
0.26^{b}\end{array}$ & $\begin{array}{c}11.88 \pm \\
0.70^{\mathrm{b}}\end{array}$ \\
\hline FFJ & & $\begin{array}{l}1.34 \pm \\
0.09^{\mathrm{a}}\end{array}$ & $\begin{array}{c}49.28 \pm \\
3.43^{\mathrm{b}}\end{array}$ & $\begin{array}{l}4.47 \pm \\
0.20^{c}\end{array}$ & $\begin{array}{l}3.62^{ \pm} \\
0.22^{c}\end{array}$ & $\begin{array}{l}1.27 \pm \\
0.31^{b}\end{array}$ & $\begin{array}{l}11.05 \mathrm{D} \\
1.49^{\mathrm{bc}}\end{array}$ \\
\hline FFJBC & & $\begin{array}{l}1.11 \pm \\
0.10^{b}\end{array}$ & $\begin{array}{c}58.21 \pm \\
3.87^{a}\end{array}$ & $\begin{array}{l}5.32 \pm \\
0.16^{a}\end{array}$ & $\begin{array}{l}4.86 \pm \\
0.22^{a}\end{array}$ & $\begin{array}{l}1.19 \pm \\
0.25^{b}\end{array}$ & $\begin{array}{c}15.97 \pm \\
0.85^{\mathrm{a}}\end{array}$ \\
\hline
\end{tabular}

Note. Treatments are: NPK compound fertilizer as control, Fermented Plant Juice (FPJ), Fermented Plant Juice incorporated with biochar and compost (FPJBC), Fermented Fruit Juice (FFJ), and Fermented Fruit Juice incorporated with biochar and compost (FFJBC) (mean + S.D., $n=15)$. Means with the same superscript within rows are not statistically different using Tukey's at $p>0.05$ probability level.

The soil $\mathrm{pH}, \mathrm{EC}$, and $\mathrm{CEC}$ results are also shown in Table 4. The $\mathrm{pH}_{\text {water }}$ represents the acidity of the soil solution, while $\mathrm{pH}_{\mathrm{KCl}}$ indicates the acidity of the soil solution plus the reserve acidity of the soil colloids. For this reason, the $\mathrm{pH}_{\mathrm{KCl}}$ is always more acidic than $\mathrm{pH}_{\text {water. }}$. Based on the $\mathrm{pH}_{\text {water }}$ results in year 2017 and 2018, significantly high values were obtained for the mixture of fermented juices, compost, and biochar treatments (FFJBC and FPJBC), followed by the soils amended only with fermented juices (FPJ and FFJ). The lowest $\mathrm{pH}_{\text {water }}$ for both years resulted from the control treatment (NPK). A similar trend was observed for $\mathrm{pH}_{\mathrm{KCl}}$. These results indicate that addition of biochar and compost to fermented juices can reduce soil $\mathrm{pH}$, as observed for FPJBC and FFJBC. The higher soil pH associated with the biochar and compost treatments might be partly due to their chemical properties. It was reported by Sulok et al. [27] that the $\mathrm{pH}$ of the biochar was 10.1 and that of the compost was 7.82. The results in Table 4 indicate that the EC for the chemical fertilizer treatment (NPK) was significantly higher than that for the organic amendments in 2017 and 2018. These results suggest that application of NPK chemical fertilizer increases soil EC. In 2017, soil CEC was significantly improved by the fermented juices combined with biochar and compost treatments (FPJBC and FFJBC) as compared with the NPK fertilizer and fermented juices only (FPJ and FFJ). In 2018, a similar pattern was observed in which the organic amendments, particularly those which contained a combination of fermented juices, compost, and biochar, showed significantly higher CEC than the soil treated with NPK fertilizer.

The effects of the different organic amendments on soil OC, total $\mathrm{N}, \mathrm{C} / \mathrm{N}$ ratio, available $\mathrm{P}$ and exchangeable $\mathrm{K}, \mathrm{Ca}, \mathrm{Na}$ and $\mathrm{Mg}$ are presented in Table 5. In 2017 and 2018, OC of the soils treated with a combination of fermented juices, biochar, and compost (FPJBC and FFJBC) were significantly higher than those treated with NPK fertilizer and fermented juices only (FPJ and FFJ). These results suggest that the application of biochar 
and compost increases the soil OC. Regardless of the year, total N of soil treated with NPK fertilizer was significantly higher than those for all the organic amendments (FPJ, FPJBC, FFJ, and FFJBC) (Table 5). Although FPJ, FPJBC, FFJ, and FFJBC increased N by 0\%, 9\%, $10 \%$, and $33 \%$, respectively, the increase was almost within the typical $0.14 \%$ total $\mathrm{N}$ content of the Miri series soil. However, the N increases caused by FPJ, FPJBC, FFJ, and FFJBC were significantly lower compared with that of NPK. The inorganic fertilizer used for the mature pepper vines cultivation was NPK 12:12:17 compound fertilizer, which had higher $\mathrm{N}$ than the organic amendments used in this study. In contrast, the total $\mathrm{N}$ of the fermented plant juice, fermented fruit juice, biochar, and compost were $0.29 \%, 0.22 \%, 0.21 \%$, and $1.12 \%$, respectively [27].

Table 5. Treatments effects on soil total organic carbon (TOC), total nitrogen $(\mathrm{N}), \mathrm{C} / \mathrm{N}$ ratio, available phosphorus (P), exchangeable potassium (K), exchangeable calcium (Ca), exchangeable sodium ( $\mathrm{Na}$ ), and exchangeable magnesium (Mg).

\begin{tabular}{|c|c|c|c|c|c|c|c|c|c|}
\hline Treatment & Year & TOC & Total N & $\begin{array}{c}\text { C/N } \\
\text { Ratio }\end{array}$ & $\begin{array}{c}\text { Available } \\
\mathbf{P}\end{array}$ & Exch. K & Exch. Ca & Exch. Na & Exch. Mg \\
\hline & & $(\%)$ & $(\%)$ & - & (mg/kg) & \multicolumn{4}{|c|}{$(\operatorname{cmol}(+) / \mathrm{kg})$} \\
\hline NPK & & $\begin{array}{l}0.80 \pm \\
0.08^{c}\end{array}$ & $\begin{array}{l}0.40 \pm \\
0.10^{\mathrm{a}}\end{array}$ & $\begin{array}{c}2.09 \pm \\
0.45^{c}\end{array}$ & $\begin{array}{c}123.67 \pm \\
15.18^{\mathrm{b}}\end{array}$ & $\begin{array}{l}0.88 \pm \\
0.18^{a}\end{array}$ & $\begin{array}{l}0.69 \pm \\
0.10^{a}\end{array}$ & $\begin{array}{l}0.63 \pm \\
0.07^{\mathrm{a}}\end{array}$ & $\begin{array}{c}0.35 \pm \\
0.10^{a}\end{array}$ \\
\hline FPJ & 2017 & $\begin{array}{l}0.93 \pm \\
0.09^{c}\end{array}$ & $\begin{array}{l}0.11 \pm \\
0.11^{b}\end{array}$ & $\begin{array}{c}12.19 \pm \\
4.84^{\mathrm{b}}\end{array}$ & $\begin{array}{r}88.33^{ \pm} \\
6.08^{\mathrm{c}}\end{array}$ & $\begin{array}{l}0.31 \pm \\
0.13^{c}\end{array}$ & $\begin{array}{l}0.44 \pm \\
0.07^{b}\end{array}$ & $\begin{array}{l}0.17 \pm \\
0.03^{b}\end{array}$ & $\begin{array}{l}0.22 \pm \\
0.06^{c}\end{array}$ \\
\hline FPJBC & & $\begin{array}{l}1.47 \pm \\
0.08^{a}\end{array}$ & $\begin{array}{l}0.10 \pm \\
0.05^{b}\end{array}$ & $\begin{array}{l}19.05 \pm \\
10.96^{\mathrm{ab}}\end{array}$ & $\begin{array}{c}167.00 \pm \\
13.71^{\mathrm{a}}\end{array}$ & $\begin{array}{l}0.82 \pm \\
0.18^{a}\end{array}$ & $\begin{array}{l}0.74 \pm \\
0.09^{\mathrm{a}}\end{array}$ & $\begin{array}{l}0.15 \pm \\
0.03 \mathrm{bc}\end{array}$ & $\begin{array}{l}0.28 \pm \\
0.06^{b}\end{array}$ \\
\hline FFJ & & $\begin{array}{l}1.24 \pm \\
0.28^{b}\end{array}$ & $\begin{array}{l}0.09 \pm \\
0.05^{b}\end{array}$ & $\begin{array}{l}16.72 \pm \\
11.35^{\mathrm{ab}}\end{array}$ & $\begin{array}{c}165.01 \pm \\
10.29^{\mathrm{a}}\end{array}$ & $\begin{array}{l}0.46 \pm \\
0.09^{b}\end{array}$ & $\begin{array}{l}0.53 \pm \\
0.15^{b}\end{array}$ & $\begin{array}{l}0.12 \pm \\
0.04 \mathrm{~cd}\end{array}$ & $\begin{array}{l}0.32 \pm \\
0.02 \mathrm{ab}\end{array}$ \\
\hline FFJBC & & $\begin{array}{l}1.56 \pm \\
0.08^{a}\end{array}$ & $\begin{array}{l}0.08 \pm \\
0.03^{b}\end{array}$ & $\begin{array}{c}20.89 \pm \\
7.02^{\mathrm{a}}\end{array}$ & $\begin{array}{c}156.50 \pm \\
13.49^{\mathrm{a}}\end{array}$ & $\begin{array}{c}0.80 \pm \\
0.09^{a}\end{array}$ & $\begin{array}{c}0.65 \pm \\
0.12^{a}\end{array}$ & $\begin{array}{l}0.10 \pm \\
0.04 \mathrm{~d}\end{array}$ & $\begin{array}{l}0.28 \pm \\
0.04^{\mathrm{b}}\end{array}$ \\
\hline NPK & & $\begin{array}{c}0.75 \pm \\
0.09^{b}\end{array}$ & $\begin{array}{l}0.53 \pm \\
0.09^{a}\end{array}$ & $\begin{array}{l}1.46^{ \pm} \\
0.15^{\mathrm{c}}\end{array}$ & $\begin{array}{c}202.07 \pm \\
31.35^{\mathrm{a}}\end{array}$ & $\begin{array}{c}0.90 \pm \\
0.06^{\mathrm{a}}\end{array}$ & $\begin{array}{l}0.71 \pm \\
0.11^{b}\end{array}$ & $\begin{array}{l}0.72 \pm \\
0.04^{\mathrm{a}}\end{array}$ & $\begin{array}{l}0.42 \pm \\
0.06^{\mathrm{a}}\end{array}$ \\
\hline FPJ & 2018 & $\begin{array}{l}0.70 \pm \\
0.06^{b}\end{array}$ & $\begin{array}{l}0.11 \pm \\
0.04^{b}\end{array}$ & $\begin{array}{l}7.55 \pm \\
2.99 \mathrm{~b}\end{array}$ & $\begin{array}{c}78.95 \pm \\
10.41^{\mathrm{d}}\end{array}$ & $\begin{array}{c}0.31 \pm \\
0.03^{c}\end{array}$ & $\begin{array}{l}0.40 \pm \\
0.04^{\mathrm{c}}\end{array}$ & $\begin{array}{l}0.12 \pm \\
0.02 \mathrm{bc}\end{array}$ & $\begin{array}{l}0.21 \pm \\
0.04^{\mathrm{d}}\end{array}$ \\
\hline FPJBC & & $\begin{array}{c}2.06 \pm \\
0.28^{a}\end{array}$ & $\begin{array}{l}0.11 \pm \\
0.02^{b}\end{array}$ & $\begin{array}{c}19.30 \pm \\
3.87^{\mathrm{a}}\end{array}$ & $\begin{array}{c}179.93 \pm \\
8.06^{\mathrm{b}}\end{array}$ & $\begin{array}{c}0.89 \pm \\
0.05^{\mathrm{a}}\end{array}$ & $\begin{array}{l}0.82 \pm \\
0.06^{a}\end{array}$ & $\begin{array}{l}0.14 \pm \\
0.03^{b}\end{array}$ & $\begin{array}{l}0.25 \pm \\
0.03^{\mathrm{cd}}\end{array}$ \\
\hline FFJ & & $\begin{array}{l}0.85 \pm \\
0.07^{b}\end{array}$ & $\begin{array}{l}0.10 \pm \\
0.02{ }^{b}\end{array}$ & $\begin{array}{l}9.26 \pm \\
1.78^{\mathrm{b}}\end{array}$ & $\begin{array}{c}101.62 \pm \\
5.66^{\mathrm{c}}\end{array}$ & $\begin{array}{c}0.39 \pm \\
0.02^{b}\end{array}$ & $\begin{array}{l}0.46^{ \pm} \\
0.06^{c}\end{array}$ & $\begin{array}{l}0.10 \pm \\
0.03^{c}\end{array}$ & $\begin{array}{l}0.29 \pm \\
0.05 \mathrm{bc}\end{array}$ \\
\hline FFJBC & & $\begin{array}{c}2.06 \pm \\
0.23^{a}\end{array}$ & $\begin{array}{l}0.12 \pm \\
0.02^{b}\end{array}$ & $\begin{array}{c}18.73 \pm \\
4.93^{\mathrm{a}}\end{array}$ & $\begin{array}{c}175.55 \pm \\
7.45^{\mathrm{b}}\end{array}$ & $\begin{array}{c}0.90 \pm \\
0.05^{\mathrm{a}}\end{array}$ & $\begin{array}{l}0.81 \pm \\
0.06^{a}\end{array}$ & $\begin{array}{l}0.12 \pm \\
0.03 \mathrm{bc}\end{array}$ & $\begin{array}{l}0.30 \pm \\
0.05^{b}\end{array}$ \\
\hline
\end{tabular}

Note. Treatments are NPK compound fertilizer as control, Fermented Plant Juice (FPJ), Fermented Plant Juice incorporated with biochar and compost (FPJBC), Fermented Fruit Juice (FFJ and Fermented Fruit Juice incorporated with biochar and compost (FFJBC) (mean + S.D., $n=15$ ). Means with same letter superscript within rows are not statistically different using Tukey's at $p>0.05$ probability level.

The soil C/N ratio results in 2017 and 2018 were similar. Soils treated with a combination of fermented juices, biochar, and compost showed higher $\mathrm{C} / \mathrm{N}$ ratios in 2017 $(\mathrm{FPJBC}=19.05$ and $\mathrm{FFJBC}=20.89)$ and $2018(\mathrm{FPJBC}=19.30$ and $\mathrm{FFJBC}=18.73)$. In 2017, the soil treated with only fermented plant juice (FPJ) and fermented fruit juice (FFJ) resulted in $\mathrm{C} / \mathrm{N}$ ratios of 12.19 and 16.72, respectively, whereas in 2018 , the $\mathrm{C} / \mathrm{N}$ ratios of FPJ and FFJ were 7.55 and 9.26, respectively. Irrespective of the year, $\mathrm{C} / \mathrm{N}$ ratios of the NPK fertilizer treatments were the lowest. In 2017, except for FPJ, soil-available P was significantly higher for the fermented juices with biochar and compost treatments in comparison with NPK fertilizer treatment (Table 5). However, in 2018, the NPK-treated plots showed higher soil-available $\mathrm{P}$, followed by those treated with a combination of fermented juices, biochar, and compost (FPJBC and FFJBC) and fermented juices only (FPJ and FFJ). The higher soil-available P for the FPJBC and FFJBC treatments compared with FPJ and FFJ could be attributed to the presence of biochar and compost in the FPJBC and FFJBC treatments.

The results for the soil-exchangeable bases $(\mathrm{K}, \mathrm{Ca}, \mathrm{Na}$, and $\mathrm{Mg}$ ) for the various treatments for 2017 and 2018, as shown in Table 5, indicate a similar pattern for soilexchangeable $\mathrm{K}$ in 2017 and 2018 wherein treatments NPK, FPJBC, and FFJBC showed 
significantly higher values followed by treatments FFJ and FPJ. The results suggest that the application of fermented juices, biochar, and compost increased soil $\mathrm{K}$, although the content was comparable to that of the NPK fertilizer treatment. The soil-exchangeable Ca results also revealed a similar pattern. In 2017, the soil Ca was higher for NPK, FPJBC, and FFJBC, whereas in 2018, it was higher in the soils treated with a combination of fermented juices, biochar, and compost (FPJBC and FFJBC) followed by the NPK and fermented juices-treated plots (FPJ and FFJ). The results for soil-exchangeable Na revealed a different trend. In 2017 and 2018, soil exchangeable Na and Mg were higher in the NPK-treated plots than in the plots treated with organic amendments.

\subsection{Effects of Treatments on Soil Microbes, Temperature and Respiration}

Soil temperature, soil respiration, and soil microbial counts for the various treatments are shown in Table 6. In 2017, the soil temperature in relation to treatments was in the descending order of: NPK $>$ FFJ $>$ FPJBC $>$ FFJBC $>$ FPJ with mean values of $32.56>29.78$ $>28.58>29.91>27.38^{\circ} \mathrm{C}$, respectively. In 2018 , the soil temperature values in descending order were: $31.57>29.21>29.02>28.55>28.45^{\circ} \mathrm{C}$ for NPK $>$ FFJ $>$ FPJ $>$ FPJBC $>$ FFJBC, respectively. These results indicate that the soils with organic treatments, especially those with biochar and compost, were cooler compared with those treated with NPK fertilizer.

Table 6. Treatments effects on soil temperature, soil respiration, and bacteria, actinomycetes and fungi counts.

\begin{tabular}{|c|c|c|c|c|c|c|}
\hline Treatment & Year & $\begin{array}{c}\text { Soil } \\
\text { Temperature } \\
\left({ }^{\circ} \mathrm{C}\right)\end{array}$ & $\begin{array}{c}\text { Soil } \\
\text { Respiration } \\
\left(\mu \mathrm{molm}^{-2} \mathrm{~s}^{-1}\right)\end{array}$ & $\begin{array}{c}\text { Bact. in } 1 \mathrm{~g} \text { of } \\
\text { Dry Soil } \\
\left(\times 10^{6} \text { Cells } / g\right)\end{array}$ & $\begin{array}{l}\text { Actino. in } 1 \mathrm{~g} \\
\text { of Dry Soil } \\
\left(\times 10^{3} \text { Cells } / g\right)\end{array}$ & $\begin{array}{c}\text { Fungi in } 1 \mathrm{~g} \text { of } \\
\text { Dry Soil } \\
\left(\times 10^{3} \text { Cells } / g\right)\end{array}$ \\
\hline NPK & \multirow{5}{*}{2017} & $\begin{array}{c}32.56 \pm \\
0.76^{\mathrm{a}}\end{array}$ & $\begin{array}{c}2.20 \pm \\
0.25^{c}\end{array}$ & $\begin{array}{c}10.33 \pm \\
2.85 \mathrm{~d}\end{array}$ & $\begin{array}{c}25.33 \pm \\
2.61^{\mathrm{b}}\end{array}$ & $\begin{array}{c}4.07 \pm \\
2.05^{c}\end{array}$ \\
\hline FPJ & & $\begin{array}{c}27.38 \pm \\
0.54\end{array}$ & $\begin{array}{l}4.87 \pm \\
0.16^{\mathrm{b}}\end{array}$ & $\begin{array}{c}14.73 \pm \\
2.19^{\mathrm{c}}\end{array}$ & $\begin{array}{c}31.67 \pm \\
1.76^{\mathrm{a}}\end{array}$ & $\begin{array}{l}6.93 \pm \\
1.98^{\mathrm{b}}\end{array}$ \\
\hline FPJBC & & $\begin{array}{c}28.58 \pm \\
0.72^{\mathrm{c}}\end{array}$ & $\begin{array}{c}6.11 \pm \\
0.26^{\mathrm{a}}\end{array}$ & $\begin{array}{c}18.67 \pm \\
2.35^{b}\end{array}$ & $\begin{array}{c}34.20 \pm \\
2.40^{\mathrm{a}}\end{array}$ & $\begin{array}{c}12.13^{ \pm} \\
2.40^{\mathrm{a}}\end{array}$ \\
\hline $\mathrm{FFJ}$ & & $\begin{array}{c}29.78 \pm \\
1.24^{\mathrm{b}}\end{array}$ & $\begin{array}{l}4.99 \pm \\
0.13^{b}\end{array}$ & $\begin{array}{c}13.40 \pm \\
2.17^{\mathrm{c}}\end{array}$ & $\begin{array}{c}33.87 \pm \\
3.54^{\mathrm{a}}\end{array}$ & $\begin{array}{c}4.27 \pm \\
4.36^{\mathrm{c}}\end{array}$ \\
\hline FFJBC & & $\begin{array}{c}27.91 \pm \\
0.48^{\mathrm{cd}}\end{array}$ & $\begin{array}{c}5.96 \pm \\
0.30^{\mathrm{a}}\end{array}$ & $\begin{array}{c}24.13 \pm \\
2.80^{\mathrm{a}}\end{array}$ & $\begin{array}{c}33.67 \pm \\
2.55^{\mathrm{a}}\end{array}$ & $\begin{array}{c}13.00 \pm \\
6.17^{\mathrm{a}}\end{array}$ \\
\hline NPK & \multirow{5}{*}{2018} & $\begin{array}{c}31.57 \pm \\
0.03^{\mathrm{a}}\end{array}$ & $\begin{array}{l}1.87 \pm \\
0.08^{\mathrm{d}}\end{array}$ & $\begin{array}{l}7.13 \pm \\
2.03\end{array}$ & $\begin{array}{c}19.93 \pm \\
3.33^{\mathrm{d}}\end{array}$ & $\begin{array}{l}3.20 \pm \\
1.78^{\mathrm{b}}\end{array}$ \\
\hline FPJ & & $\begin{array}{c}29.02 \pm \\
0.02 \text { c }\end{array}$ & $\begin{array}{c}3.64 \pm \\
0.17^{\mathrm{b}}\end{array}$ & $\begin{array}{c}16.27 \pm \\
3.45^{\mathrm{b}}\end{array}$ & $\begin{array}{c}32.67 \pm \\
5.49 \mathrm{bc}\end{array}$ & $\begin{array}{l}4.80 \pm \\
3.95 \mathrm{~b}\end{array}$ \\
\hline FPJBC & & $\begin{array}{c}28.55 \pm \\
0.03\end{array}$ & $\begin{array}{c}6.81 \pm \\
0.35^{\mathrm{a}}\end{array}$ & $\begin{array}{c}24.00 \pm \\
2.42^{\mathrm{a}}\end{array}$ & $\begin{array}{c}38.73 \pm \\
1.79^{\mathrm{a}}\end{array}$ & $\begin{array}{c}11.93 \pm \\
1.93^{\mathrm{a}}\end{array}$ \\
\hline FFJ & & $\begin{array}{c}29.21 \pm \\
0.10^{\mathrm{b}}\end{array}$ & $\begin{array}{c}2.91 \pm \\
0.19^{c}\end{array}$ & $\begin{array}{c}11.13^{ \pm} \\
3.25^{\mathrm{c}}\end{array}$ & $\begin{array}{c}29.07 \pm \\
3.52^{\mathrm{c}}\end{array}$ & $\begin{array}{l}5.00 \pm \\
1.93^{\mathrm{b}}\end{array}$ \\
\hline FFJBC & & $\begin{array}{c}28.45 \pm \\
0.04 \mathrm{e}^{\mathrm{e}}\end{array}$ & $\begin{array}{c}6.67 \pm \\
0.34^{\mathrm{a}}\end{array}$ & $\begin{array}{c}26.00 \pm \\
1.07^{\mathrm{a}}\end{array}$ & $\begin{array}{c}36.47 \pm \\
5.36^{\mathrm{ab}}\end{array}$ & $\begin{array}{c}15.20 \pm \\
4.78^{\mathrm{a}}\end{array}$ \\
\hline
\end{tabular}

Note. Treatments are NPK compound fertilizer as control, Fermented Plant Juice (FPJ), Fermented Plant Juice incorporated with biochar and compost (FPJBC), Fermented Fruit Juice (FFJ), and Fermented Fruit Juice incorporated with biochar and compost (FFJBC) (mean + S.D., $n=15$ ). Means with same letter superscript within rows are not statistically different using Tukey's at $p>0.05$ probability level.

Based on the soil respiration results for 2017 and 2018, treatments FPJBC and FFJBC resulted in higher values followed by the fermented juices-only treatments (FPJ and FFJ) and NPK fertilizer treatment. These results suggest that soil $\mathrm{CO}_{2}$ efflux increased with application of biochar, composts, and the fermented juices. The results indicate that higher soil respiration results were congruent with the results for soil microorganisms (bacteria, actinomycetes, and fungi) counts (Table 6). In 2017, the bacteria count in a $1 \mathrm{~g}$ of dry soil was higher for the combination of fermented juices, biochar, and compost treatments (FPJBC and FFJBC) followed by the fermented juices-only (FPJ and FFJ) and NPK fertilizer treatments. In 2018, the combination of fermented juices, biochar, and compost treatments 
(FPJBC and FFJBC) showed the highest bacteria count, followed by fermented juices-only (FPJ and FFJ), and NPK fertilizer treatments. Almost similar patterns were observed for actinomycetes and fungi counts wherein the soils treated with organic amendments especially those with biochar and compost were significantly higher than that of the NPK fertilizer.

Regression analysis revealed a strong relationship between soil respiration and soil microorganisms (bacteria, actinomycetes, and fungi). The relationship between soil respiration and soil bacteria count is shown in Figure 1. The relationship was best described by a quadratic equation line with $R^{2}=0.87$. The results indicate a significant positive relationship between the two factors with increase in soil respiration as soil bacteria count increases. A total of $87 \%$ of the variation in soil respiration is explained by the quadratic relationship with soil bacterial count.

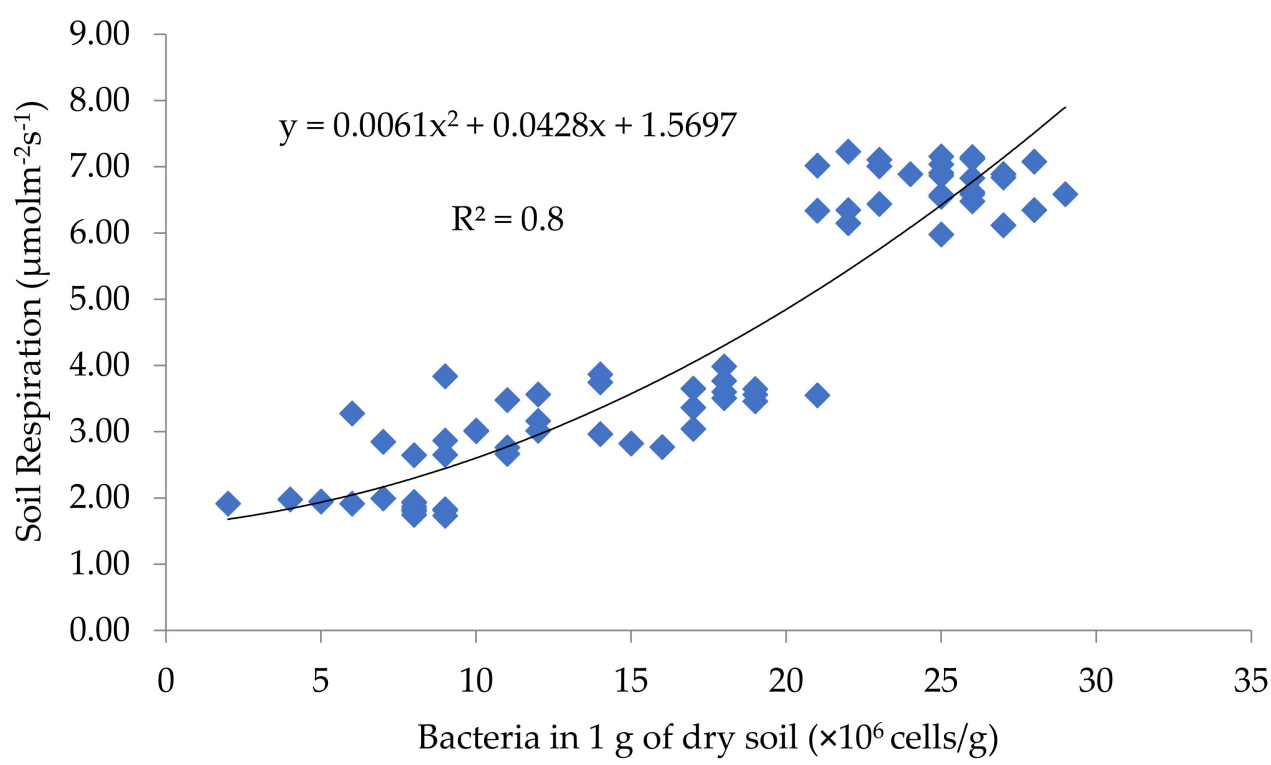

Figure 1. Relationship between soil bacteria count and soil respiration.

Similarly, the relationship between soil respiration and soil actinomycetes count was significant with $R^{2}=0.92$ (Figure 2). The relationship between the two was best described by an exponential equation. The results indicate a significant relationship between the two factors with a slow initial increase in soil respiration followed by a rapid increase in soil respiration as soil actinomycetes count increases. A total of $92 \%$ of the variation in soil respiration is explained by the exponential relationship with soil actinomycetes count.

The relationship between soil respiration and soil fungi count was significant with $\mathrm{R}^{2}=0.86$ (Figure 3 ). The relationship between the two factors was best described by a quadratic equation, suggesting that soil respiration increased with increasing soil fungi count, but there was a time threshold where the fungi activities caused a reduction in soil respiration. The variation ( $86 \%$ ) in soil respiration is explained by the quadratic relationship with soil fungi count. 


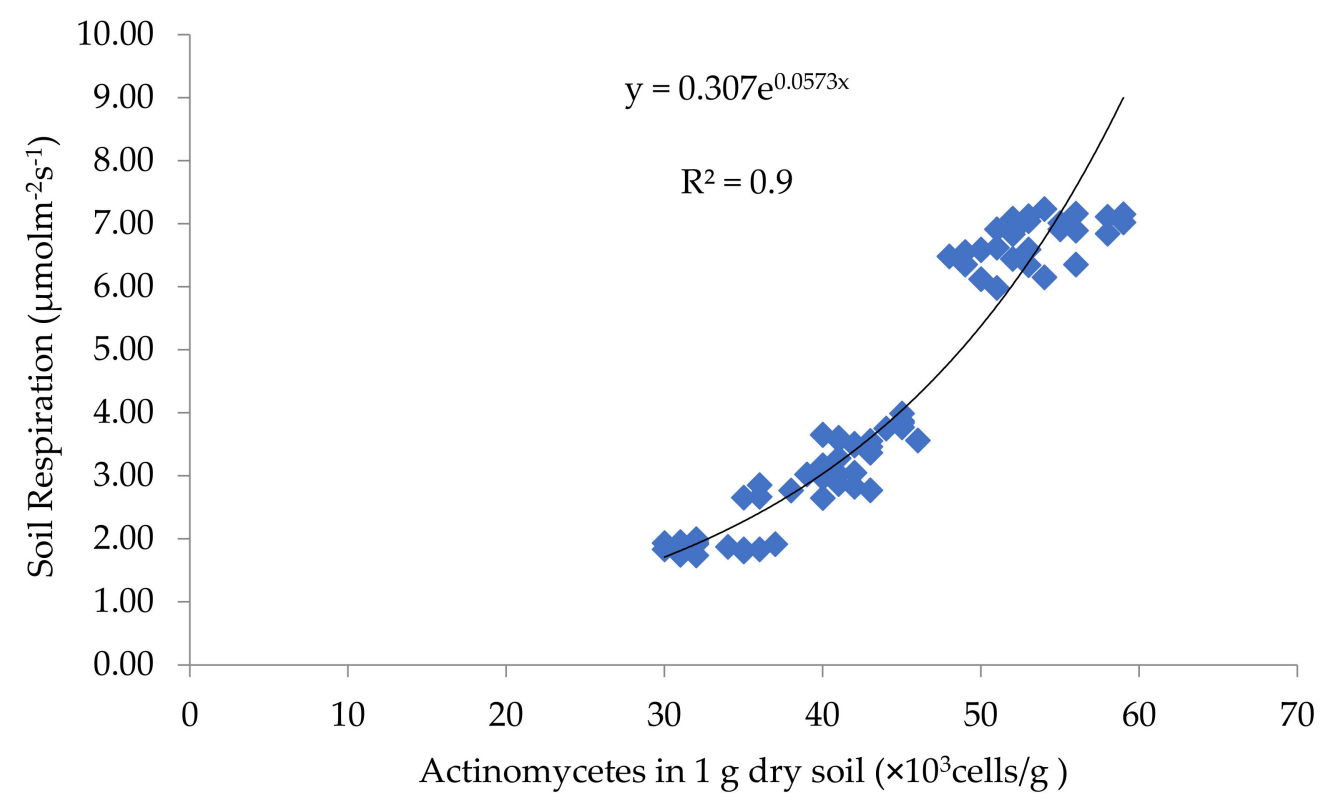

Figure 2. Relationship between soil actinomycetes count and soil respiration.

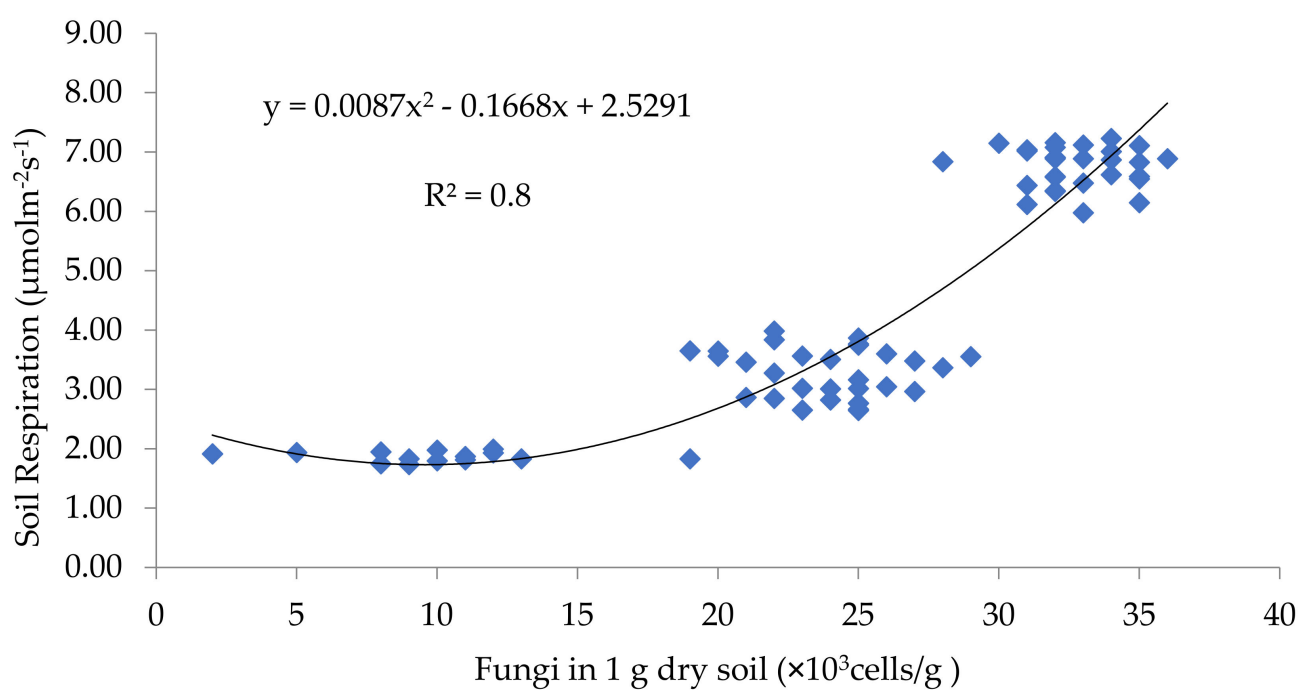

Figure 3. Relationship between soil fungi count and soil respiration.

\subsection{Pepper Physiological Characteristics}

The effects of the organic amendments on foliar chlorophyll concentration, NDVI, photosynthetic rate (A), leaf stomatal conductance rate (gs), and transpiration rate (E) of pepper grown on a sandy soil for a period of two years are presented in Table 7 . Foliar chlorophyll concentration was higher for NPK fertilizer than for all the organic amendments. The NDVI results in 2017 in ascending order were: $0.82<0.85<0.89<0.90$ $<0.95$, for treatments FFJ < FFJBC < FPJ < FPJBC < NPK, respectively. In 2018, however, FPJBC and FFJBC showed significantly higher foliar chlorophyll values followed by the fermented juicesalone (FPJ and FFJ) and NPK fertilizer treatments. At the end of this study, the fermented juices, fermented juices combined with biochar, and compost improved the NDVI of the pepper. 
Table 7. Treatments effects on Normalized Difference Vegetation Index (NDVI), foliar chlorophyll concentration, photosynthetic rate (A), leaf stomatal conductance rate (gs and transpiration rate (E).

\begin{tabular}{|c|c|c|c|c|c|c|}
\hline Treatment & Year & $\begin{array}{l}\text { Chlorophyll } \\
\text { ( } \mu \text { mol per } \mathrm{m}^{2} \\
\text { of Leaf) }\end{array}$ & NDVI & $\begin{array}{c}\text { Photosynthesis } \\
(A)(\mu \mathrm{mol} \mathrm{CO} 2 \\
\left.\mathrm{m}^{-2} \mathrm{~s}^{-1}\right)\end{array}$ & $\begin{array}{c}\text { Conductance } \\
(g s)\left(\mathrm{mol} \mathrm{H}_{2} \mathrm{O}\right. \\
\left.\mathrm{m}^{-2} \mathrm{~s}^{-1}\right)\end{array}$ & $\begin{array}{c}\text { Transiration }(E) \\
\left(\mathrm{mmol}_{2} \mathrm{O}\right. \\
\left.\mathrm{m}^{-2} \mathrm{~s}^{-1}\right)\end{array}$ \\
\hline NPK & & $\begin{array}{c}85.33 \pm \\
2.72^{a}\end{array}$ & $\begin{array}{c}0.95 \pm \\
0.04^{\mathrm{a}}\end{array}$ & $\begin{array}{l}9.78 \pm \\
0.51^{\mathrm{a}}\end{array}$ & $\begin{array}{l}0.26 \pm \\
0.03^{a}\end{array}$ & $\begin{array}{l}3.78 \pm \\
0.16^{\mathrm{a}}\end{array}$ \\
\hline FPJ & 2017 & $\begin{array}{c}80.21 \pm \\
2.31^{\mathrm{b}}\end{array}$ & $\begin{array}{l}0.89 \pm \\
0.04^{\mathrm{bc}}\end{array}$ & $\begin{array}{l}8.24 \pm \\
0.45^{b}\end{array}$ & $\begin{array}{l}0.18 \pm \\
0.02 b c\end{array}$ & $\begin{array}{l}2.78 \pm \\
0.16^{\mathrm{b}}\end{array}$ \\
\hline FPJBC & & $\begin{array}{c}81.62 \pm \\
2.25^{\mathrm{b}}\end{array}$ & $\begin{array}{l}0.90 \pm \\
0.03^{\mathrm{ab}}\end{array}$ & $\begin{array}{l}7.97 \pm \\
0.33^{b}\end{array}$ & $\begin{array}{l}0.16 \pm \\
0.03^{c}\end{array}$ & $\begin{array}{l}2.14^{ \pm} \\
0.19^{c}\end{array}$ \\
\hline FFJ & & $\begin{array}{c}79.89 \pm \\
4.86^{\mathrm{b}}\end{array}$ & $\begin{array}{l}0.82^{ \pm} \\
0.06^{\mathrm{c}}\end{array}$ & $\begin{array}{l}8.25 \pm \\
0.34^{b}\end{array}$ & $\begin{array}{l}0.19 \pm \\
0.03^{b}\end{array}$ & $\begin{array}{c}3.58 \pm \\
0.20^{\mathrm{a}}\end{array}$ \\
\hline FFJBC & & $\begin{array}{c}81.36 \pm \\
1.69^{b}\end{array}$ & $\begin{array}{c}0.85^{ \pm} \\
0.05^{c}\end{array}$ & $\begin{array}{l}8.10 \pm \\
0.33^{b}\end{array}$ & $\begin{array}{c}0.14^{ \pm} \\
0.05^{c}\end{array}$ & $\begin{array}{l}2.31 \pm \\
0.33^{c}\end{array}$ \\
\hline NPK & & $\begin{array}{c}89.71 \pm \\
4.67^{\mathrm{a}}\end{array}$ & $\begin{array}{l}0.86 \pm \\
0.03^{b}\end{array}$ & $\begin{array}{c}13.48 \pm \\
1.81^{\mathrm{a}}\end{array}$ & $\begin{array}{c}0.24 \pm \\
0.02^{\mathrm{a}}\end{array}$ & $\begin{array}{l}4.29 \pm \\
0.34^{\mathrm{a}}\end{array}$ \\
\hline FPJ & 2018 & $\begin{array}{c}82.53 \pm \\
1.64^{\mathrm{c}}\end{array}$ & $\begin{array}{l}0.85 \pm \\
0.03^{b}\end{array}$ & $\begin{array}{l}9.56 \pm \\
1.93^{b}\end{array}$ & $\begin{array}{l}0.11 \pm \\
0.06^{c}\end{array}$ & $\begin{array}{l}2.17 \pm \\
1.08^{\mathrm{c}}\end{array}$ \\
\hline FPJBC & & $\begin{array}{c}85.44 \pm \\
1.58^{\mathrm{b}}\end{array}$ & $\begin{array}{c}0.89 \pm \\
0.02^{\mathrm{a}}\end{array}$ & $\begin{array}{c}12.52 \pm \\
0.94^{\mathrm{a}}\end{array}$ & $\begin{array}{l}0.20 \pm \\
0.06^{\mathrm{ab}}\end{array}$ & $\begin{array}{l}3.93 \pm \\
0.78^{a b}\end{array}$ \\
\hline FFJ & & $\begin{array}{c}83.53 \pm \\
1.59 \mathrm{bc}\end{array}$ & $\begin{array}{l}0.86 \pm \\
0.03^{b}\end{array}$ & $\begin{array}{c}10.09 \pm \\
2.19^{\mathrm{b}}\end{array}$ & $\begin{array}{l}0.17 \pm \\
0.07^{b}\end{array}$ & $\begin{array}{l}3.22 \pm \\
1.14^{\mathrm{b}}\end{array}$ \\
\hline FFJBC & & $\begin{array}{c}85.47 \pm \\
1.70^{\mathrm{b}}\end{array}$ & $\begin{array}{c}0.89 \pm \\
0.02^{a}\end{array}$ & $\begin{array}{c}13.16 \pm \\
1.48^{\mathrm{a}}\end{array}$ & $\begin{array}{c}0.24 \pm \\
0.02^{\mathrm{a}}\end{array}$ & $\begin{array}{l}4.25 \pm \\
0.24^{\mathrm{a}}\end{array}$ \\
\hline
\end{tabular}

Note. Treatments are: NPK compound fertilizer as control, Fermented Plant Juice (FPJ), Fermented Plant Juice incorporated with biochar and compost (FPJBC), Fermented Fruit Juice (FFJ and Fermented Fruit Juice incorporated with biochar and compost (FFJBC) (mean + S.D. $n=15$ ). Means with same superscript within rows are not statistically different using Tukey's at $p>0.05$ probability level.

The pepper leaves gas exchange results shown in Table 7 indicate similar patterns with pepper photosynthesis, stomatal conductance, and transpiration rates. In 2017, the pepper vines' photosynthesis, stomatal conductance, and transpiration in the NPK treatment plots were higher than that for the organic amended plots. In 2018, the NPK-treated plots and combination of fermented juices with biochar and compost amendments (FPFBC and FFJBC) resulted in significantly higher pepper plants gas exchange rates compared with those treated with fermented juices only (FPJ and FFJ). It is worth noting that both biochar and compost amendments were essentially the cause of the higher gas exchange rates in FPJBC and FFJBC.

The relationship between foliar chlorophyll concentration of pepper plants and soil total $\mathrm{N}$ are shown in Figure 4. The positive linear relationship suggests that foliar chlorophyll concentration increases with increasing soil total N. A total of $53 \%$ of the variation in leaf chlorophyll content is explained by the linear relationship with soil total $\mathrm{N}$.

On the other hand, there was a negative relationship between pepper NDVI and soil total $\mathrm{N}$, with $\mathrm{R}^{2}=0.42$, as shown in Figure 5 . The relationship between the two factors was best described by a quadratic regression, with $42 \%$ of the variation in NDVI explained by this quadratic relationship with soil total $\mathrm{N}$. The weak relationship was due to the high pepper NDVI values for the soils treated with a mixture of fermented juices with biochar and compost (FPJBC and NPK). At the same time, soil total N for FPJBC and FFJBC was lower than that of NPK, resulting in a low determination coefficient $\left(R^{2}\right)$ value for the relationship. 


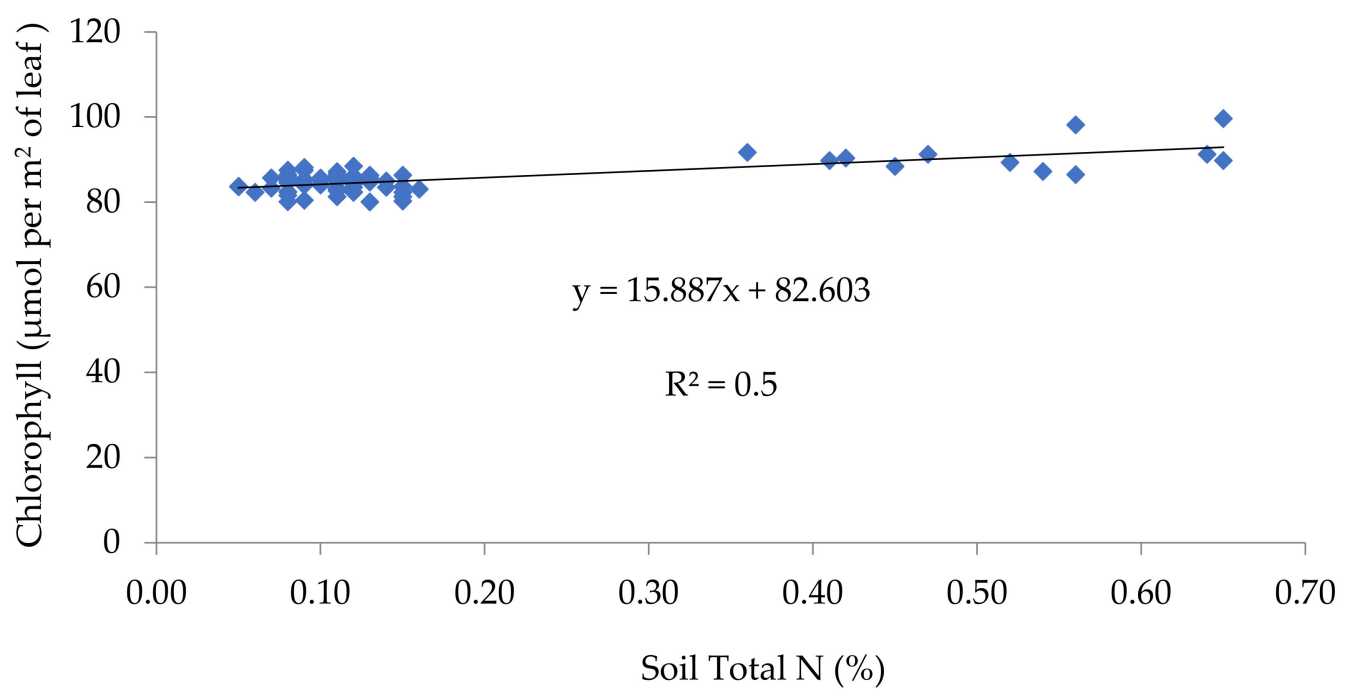

Figure 4. Relationship between foliar chlorophyll concentration of pepper plants and soil total N.

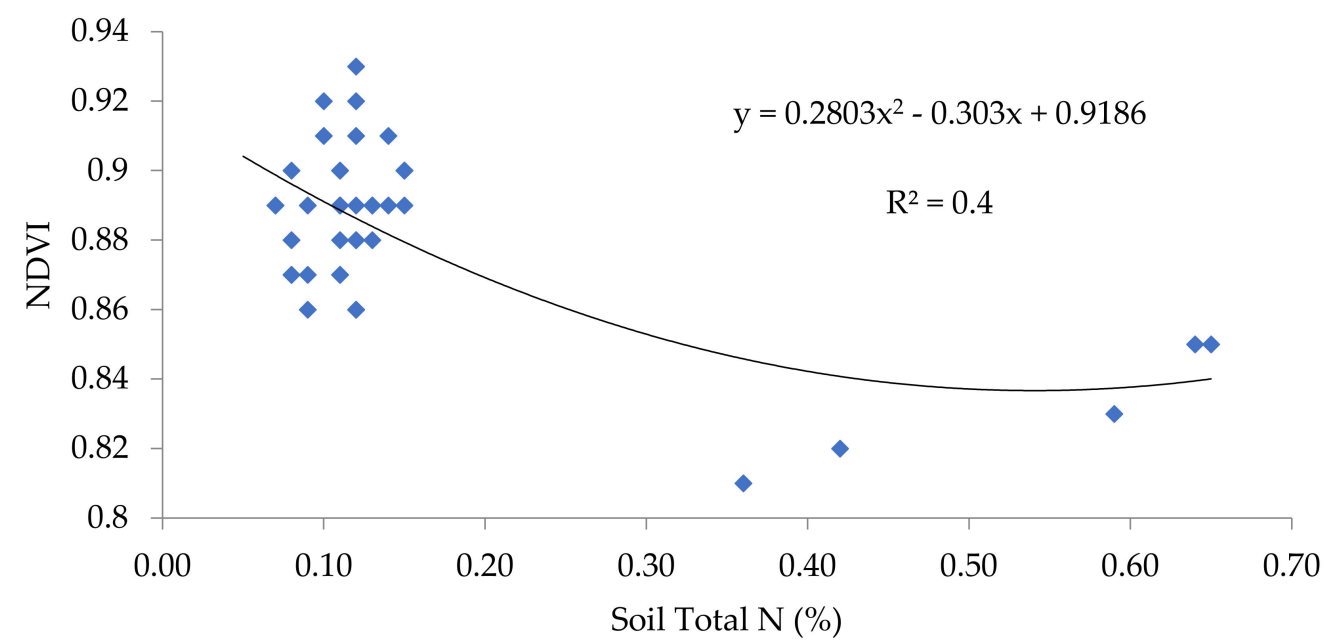

Figure 5. Relationship between normalized difference vegetation index (NDVI) of pepper plants and soil total N.

The photosynthesis rate of pepper plants and soil total $\mathrm{N}$ showed a weak relationship with $\mathrm{R}^{2}=0.35$ (Figure 6). The relationship between the two factors was best described by a quadratic equation, with $35 \%$ of the variation in photosynthesis rate explained by the quadratic relationship with soil total $\mathrm{N}$. 


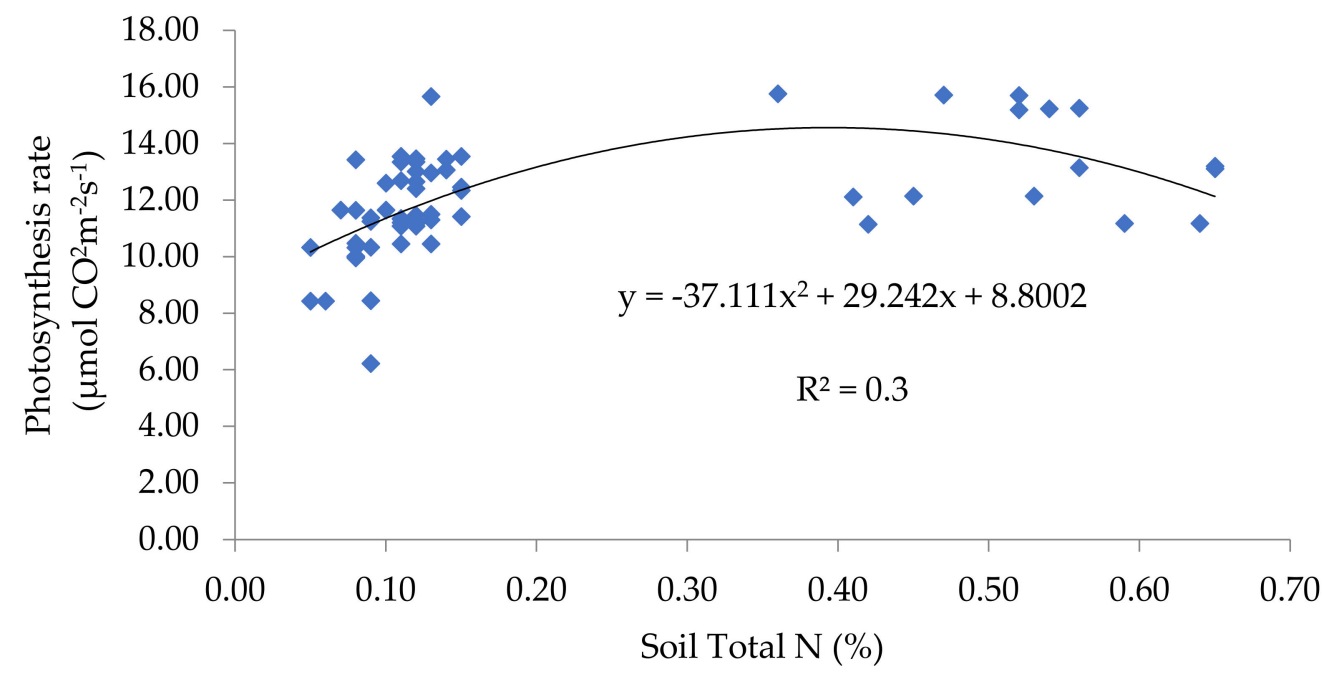

Figure 6. Relationship between photosynthetic rates of pepper leaves and soil total N.

\subsection{Pepper Morphological Characteristics and Fresh Berry Yield}

The average fruit spike lengths of the pepper treated with organic soil amendments and NPK fertilizer are shown in Figure 7. In 2017, all the organic amendments showed significantly lower fruit spike length compared with that for the NPK fertilizer treatment.

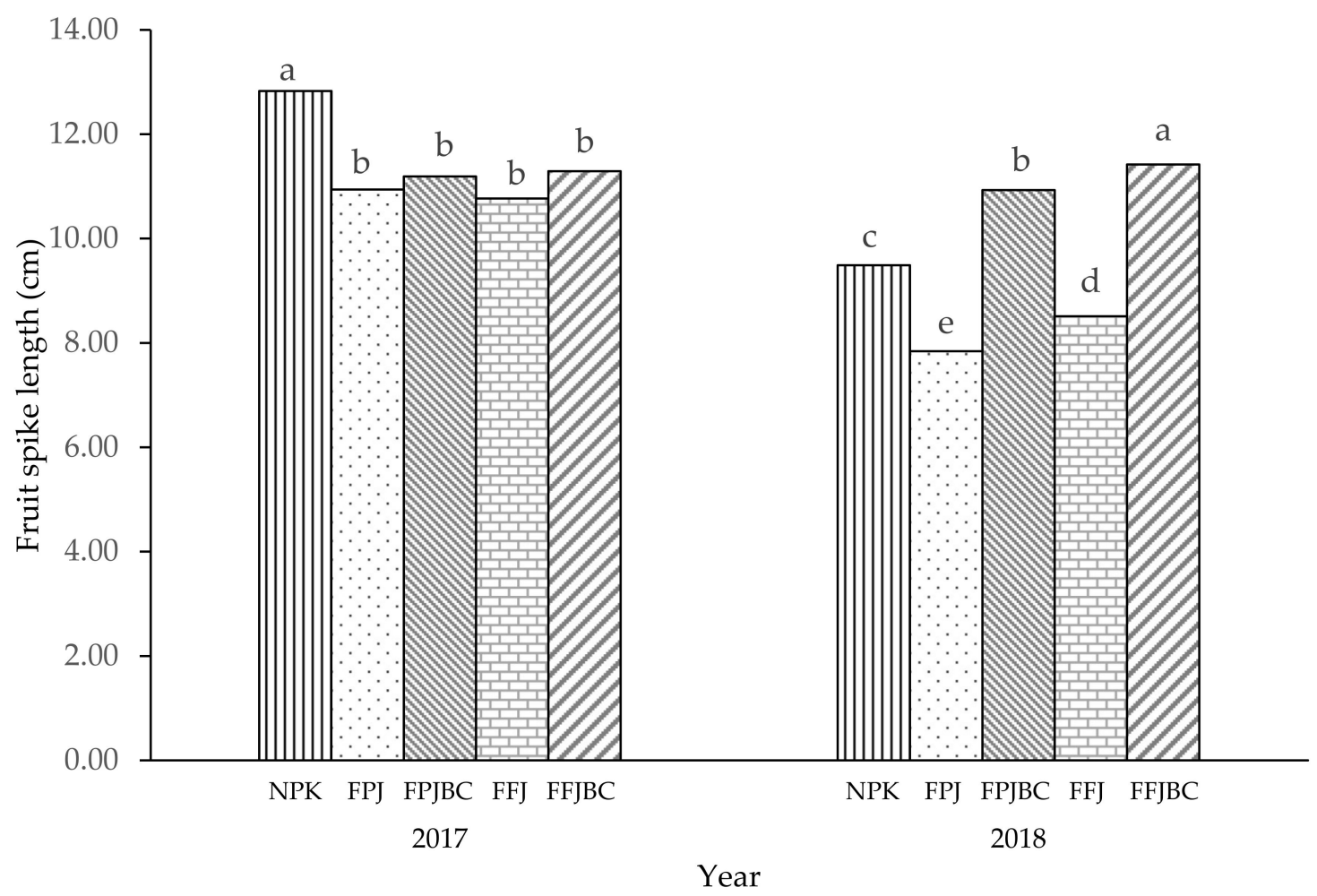

Figure 7. Average length of pepper fruit spike in 2017 and 2018 for different soil amendments. Treatments are: NPK compound fertilizer as control, Fermented Plant Juice (FPJ), Fermented Plant Juice incorporated with biochar and compost (FPJBC), Fermented Fruit Juice (FFJ and Fermented Fruit Juice incorporated with biochar and compost (FFJBC). Note. Bars (representing the means) with same letters within a year are not statistically different using Tukey's at $p>0.05$ probability level.

However, in 2018, the fermented fruit juice combined with biochar and compost treatment (FFJBC) resulted in the highest fruit spike length $(11.42 \mathrm{~cm})$, followed by fermented 
plant juice combined with biochar and compost treatment $(\mathrm{FPJBC}=10.93 \mathrm{~cm})$, chemical fertilizer treatment $(\mathrm{NPK}=9.49 \mathrm{~cm})$, fermented fruit juice-only treatment $(\mathrm{FFJ}=8.51 \mathrm{~cm})$, and fermented plant juice-only treatment $(\mathrm{FPJ}=7.84 \mathrm{~cm})$. These results also indicate that from 2017 to 2018, the length of the pepper fruit spikes for treatments NPK, FPJ, and FFJ were reduced by $26 \%, 30 \%$, and $21 \%$, respectively.

The average leaf area indexes (LAI) of the pepper vines for the organic soil amendments and the NPK treatment are presented in Figure 8. NPK treatment resulted in the highest LAI (7.79) in 2017 followed by FFJBC (6.63), FPJBC (6.57), FPJ (6.32), and FFJ (5.93). Similar results were obtained in 2018, whereby the NPK fertilizer treatment maintained the highest LAI values compared with those of the organic soil amendments. The LAI for the NPK treatment increased by $8 \%$ (2017 to 2018), whereas FPJ, FPJBC, FFJ, and FFJBC (organic amendments) increased LAI by 1\%, 4\%, 12\%, and 3\%, respectively, from 2017 to 2018.

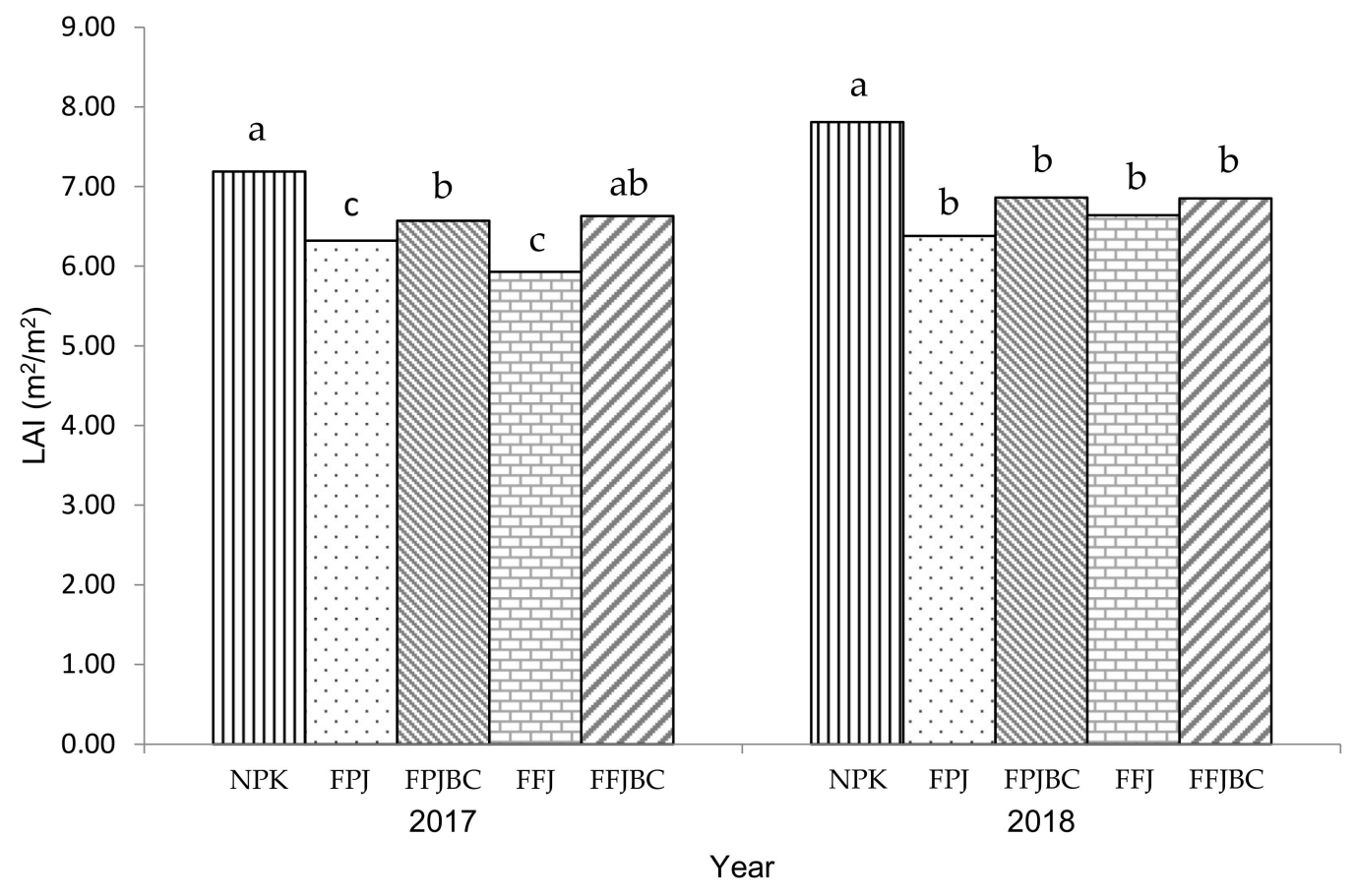

Figure 8. Average Leaf Area Index (LAI) of pepper vines in 2017 and 2018 for different soil amendments. Treatments are: NPK compound fertilizer as control, Fermented Plant Juice (FPJ), Fermented Plant Juice incorporated with biochar and compost (FPJBC), Fermented Fruit Juice (FFJ and Fermented Fruit Juice incorporated with biochar and compost (FFJBC) Note. Bars (representing the means) with same letters within a year are not statistically different using Tukey's at $p>0.05$ probability level.

Fresh berry yields in 2017 and 2018 for the different soil treatments are shown in Figure 9. In 2017, fresh berry yields in ascending order were: $10.47<10.59<10.63<10.94<$ $11.78 \mathrm{~kg}$ for FFJ $<$ FFJBC $<$ FPJ $<$ FPJBC $<$ NPK, respectively. A different trend was observed in 2018, whereby fresh berry yields in ascending order were: $8.43<8.90<11.36<12.46<$ $12.56 \mathrm{~kg}$ for FFJ $<$ FPJ $<$ NPK $<$ FPJBC $<$ FFJBC, respectively. These findings suggest that from 2017 to 2018, the fresh berry yields of NPK, FPJ, and FFJ reduced by $4 \%, 6 \%$, and $20 \%$, respectively, for the fermented juices-only treatment applications. However, the fresh berry yields of FPJBC and FFJBC increased by $14 \%$ and $19 \%$, respectively. 


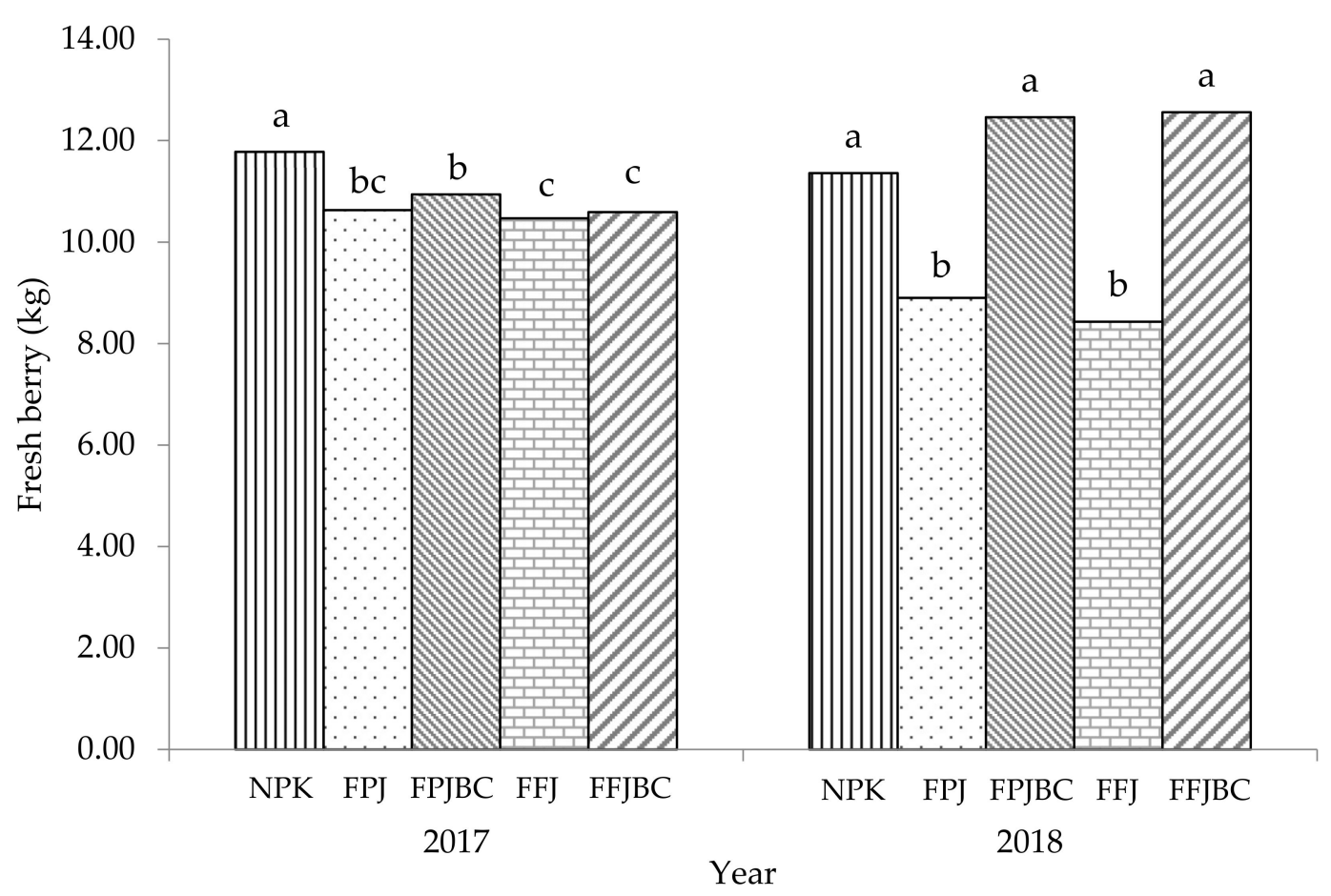

Figure 9. Average fresh berry yields of pepper in year 2017 and 2018 for different soil amendments. Treatments are: NPK compound fertilizer as control, Fermented Plant Juice (FPJ), Fermented Plant Juice incorporated with biochar and compost (FPJBC), Fermented Fruit Juice (FFJ), and Fermented Fruit Juice incorporated with biochar and compost (FFJBC). Note. Bars (representing the means) with same letters within a year are not statistically different using Tukey's at $p>0.05$ probability level.

\section{Discussion}

\subsection{Soil Physical and Chemical Properties}

The International Biochar Initiative [34] reported that the effects of biochars and composts on soil bulk density and porosity occur regardless of biochar type, duration of study, and soil type, but sandy soils appear to be more responsive to biochar application than soils with higher clay content. These results were consistent with a study carried out by Javaid and Bajwa [35], who also reported that because of the ability of beneficial microorganisms to form highly permeable humus from decomposed plant materials, soil bulk density is reduced significantly in compost-treated soils. Furthermore, [36,37] documented that biochar and low-density organic matter of compost, when mixed with mineral soils, were able to increase porosity and at the same time decrease overall soil weight and bulk density. In a report by [38], they stated that bulk density of mineral soils of 1.1 to $1.5 \mathrm{~g} / \mathrm{cm}^{3}$ (bulk density) in surface horizons are generally ideal for pepper cultivation as this range enables the crop's roots to extend their scavenging for available nutrients and water.

Generally, the results (Table 4) showed that the combination of fermented juices, compost, and biochar significantly improved soil $\mathrm{pH}, \mathrm{EC}$, and CEC. This finding is consistent with a study by [35] who posited that decomposition of organic matter by beneficial microorganisms induced by incorporation of biochar and compost can increase soil $\mathrm{pH}$. Additionally, Tedersoo and Smith [39] found that biochar and compost provide an environment or habitat that is favorable for microbial communities to multiply and, thus, increase decomposition of organic matter. The increase in soil $\mathrm{pH}$ in this study might otherwise be attributed to biochar alone as it has a high ash content (5.22\%), as reported in [27]. The NPK fertilizer increased soil EC (Table 4) because chemical fertilizers are relatively high in $\mathrm{N}$ and $\mathrm{Na}$, which are salts and are water soluble [40]. Sanchez et al. [41] found that soil $\mathrm{pH}$ and EC are inversely related and they suggested that soils with higher $\mathrm{pH}$ will be low in EC. Cation exchange capacity is one of the most important indicators of 
soil fertility, more specifically for nutrient retention to prevent or minimize leaching of cations from soil which reduces crop uptake [42]. The fermented juices with biochar and compost significantly improved CEC, indicating improved retention of non-acidic cations principally because of the cation holding ability of the biochar and composts through their carboxylic, phenolic, and alcoholic functional groups [43,44]. Nigussie et al. [45] found that the use of biochar-compost mixture in soils can lead to improved physico-chemical properties, particularly that of $\mathrm{CEC}, \mathrm{pH}$, and bulk density. In a related study, [46] also revealed that biochar-compost amendments increased CEC because of the rich functional groups associated with organic compounds, such as humic, fulvic, oxazlic, and malic acids, among others. According to [47], soil organic matter contributes between $20 \%$ and $70 \%$ to the CEC of many soils. In absolute terms, CEC of organic matter varies from 300 to 1400 $\mathrm{Cmol}_{\mathrm{C}} \mathrm{kg}^{-1}$ and it is higher than the CEC of any inorganic material. In a similar study, [48] observed that besides improved soil CEC, soil TOC was highest following biochar and compost application. Moreover, a study by [49] on a sandy soil showed that soil total $C$ was high in oil palm plantations supplied with fresh organic matter from plant parts. Ho et al. [49] added that soil TOC was the dominant contributor of soil CEC, suggesting that maintaining sufficient levels of soil total $C$ during cropping is vital for sustaining soil and crop productivity. Beneficial effects of biochar and compost on soil physico-chemical properties was also reported by [46], who found that increase in C and P retention was due to the formation of organic coating in co-composted biochar, resulting in entrapment or adsorption of dissolved nutrients.

As expected, soil total N of the NPK plots was high (Table 5), indicating the high availability of ready-to-be-released nutrients such as N, P, and $\mathrm{K}$ in the chemical fertilizer [50]. In terms of available nutrients, [40] described chemical fertilizers (compound) as being superior to organic fertilizers because in the latter the bulk of $\mathrm{P}$ and $\mathrm{N}$ are in organic form and are only released as the organic amendments decompose with time. Amlinger et al. [47] noted that a significant amount of organic $\mathrm{N}$ in composts is not readily available, but can be mineralized and subsequently taken up by plants or immobilized, denitrified, and/or leached. Nonetheless, organic soil amendments have their advantages in that they can be used as soil conditioners to enhance availability of nutrients in soils which are relatively poor in nutrients $[25,51,52]$. Ho et al. [49] also encouraged the application of organic materials such as composts for farming practices on sandy soils as the organic matter could be another source of nutrients such as N, P, and K in oil palm, pepper, and other crop cultivation. At the end of this study, the lowest and highest $\mathrm{C} / \mathrm{N}$ ratios were observed for NPK fertilizer treatment and the combination of fermented juices with biochar and compost treatments (FPJBC and FFJBC). Sanchez et al. [41] opined that the low C/N ratio of the soils with inorganic fertilizers was partly due to high mineral-N contents resulting from $\mathrm{N}$ fertilizer inputs. On the other hand, the soils with biochar and compost treatments showed higher $\mathrm{C} / \mathrm{N}$ ratios because of high $\mathrm{C}$ in these materials [42]. Doran and Zeiss [53] and Rajkovich et al. [54] revealed that $\mathrm{N}$ immobilization occurs when an organic amendment with high $\mathrm{C} / \mathrm{N}$ ratio is introduced to soils because of competition between microbes and plants for soil N. Suhaimee et al. [55] added that when organic amendments with high $\mathrm{C} / \mathrm{N}$ ratios were added to soils, they decompose slowly because the microbes need to find more $\mathrm{N}$ from other sources and this leads to higher $\mathrm{C} / \mathrm{N}$ ratios or lower $\mathrm{N}$ in soils.

Soil-available P was higher in the NPK-treated plots, although it is well known that sandy soils have poor nutrient retention capability as the dissolved P derived from the inorganic fertilizers leaches downward into the spodic horizon or is lost through surface runoff [49]. However, the results for soil-available $\mathrm{P}$ in this study are consistent with those of [40], who stated that after taking into account nutrients removal as yield and those stored within the pepper plants, the surplus of NPK fertilizers applied in pepper farms results in higher soil-available P in the soil. Nonetheless, [49] attributed the higher soil-available $\mathrm{P}$ to the application of organic amendments due to their ability to retard $\mathrm{P}$ losses in sandy soils. Ho et al. [49] added that application of manures in sandy soils reduces 
$\mathrm{P}$ fixation but this practice increases the available $\mathrm{P}$ pool because of the release of organic acids and other microbial products that modified soil $\mathrm{pH}$ during decomposition. The mixture of fermented juices, biochar, and compost also improved soil-available $\mathrm{P}$ because of the P-solubilizing microorganisms [25]. Zimmermann [56] used biochar and compost to enhance the effectiveness of the phosphate-solubilizing microbes in the soils because these amendments served as habitat and food source for them.

The higher availability of $\mathrm{K}$ for the chemical fertilizer treatment was due to the 12:12:17 NPK content in the fertilizer. Paulus [28] stated that in fertilizing mature pepper vines, compound fertilizer (12:12:17) is most suitable because of the availability of higher $\mathrm{K}$ and trace elements such as $\mathrm{Na}$ and $\mathrm{Mg}$ which are readily taken up by the pepper vines. The increase in soil $\mathrm{K}$ contents following the application of fermented juices, biochar, and compost was most likely due to the interaction between the beneficial microorganisms in the fermented juices with the biochar and compost. It was reported in [27] that the fermented juices were composed of beneficial microorganisms such as Bacillus sp., Sporosarcina sp., and Aspergillus sp. which are able to convert insoluble $\mathrm{K}$ into soluble $\mathrm{K}$ for crop use. In a study reported by [25], it was also mentioned that soils with co-composted biochar and inoculated with beneficial microbes such as K solubilizers can increase soil-exchangeable $\mathrm{K}$. Other factors which might have contributed to the higher soil-exchangeable $\mathrm{K}, \mathrm{Ca}$, and $\mathrm{Mg}$ were related to the favorable properties of the biochar and compost. Lehmann et al. [43] stated that biochars are not only soil conditioners which are able to increase CEC, but they could also serve as fertilizers. As biochar contain ash which releases base cations such as $\mathrm{K}, \mathrm{Ca}$, and $\mathrm{Mg}$ into the soil solution, their liming effects improve soil $\mathrm{pH}$ and nutrients availability for crop growth and development [44]. Previous studies suggest that the fertilizing effect of $\mathrm{K}$ in biochar is critical for increasing soil-exchangeable $\mathrm{K}$ and promoting crop growth [57-59]. Agegnehu et al. [60] reported that depending on the organic materials used and compost-processing conditions, composts contain significant amounts of valuable plant macro and micro-nutrients, such as $\mathrm{P}, \mathrm{K}, \mathrm{Ca}$, and $\mathrm{Cu}, \mathrm{Zn}, \mathrm{Fe}$, respectively. Thus, a well-processed compost can be used as an organic multi-nutrient fertilizer to increase soil nutrients [47]. Abideen et al. [61] documented that biochar, in combination with compost, can function as an ion exchange matrix and can bind high amounts of cations. The higher soil Ca following biochar and compost application might be due to the ash content of the biochar. The biochar used in this study had an ash content of $5.22 \%$ whereas its Ca content was $6977 \mathrm{mg} / \mathrm{kg}$ [27]. In a similar study, [38,43] attributed high Ca and K contents in sandy soils to the ash in biochar.

\subsection{Soil Microbes, Temperature and Respiration}

The reduced soil temperature for fermented juices, biochar, and compost treatment in Table 6 was not in agreement with those reported by [53], who stated that application of compost rather increased soil temperature by decreasing water evaporation from the soil surface. Javaid and Bajwa [35] added that with increasing dry weight of composts, microbial activity can also contribute to high soil temperature. However, in a similar study on a sandy soil, [61] discovered that applying biochar increased soil porosity to cause more heat losses to the atmosphere, thus reducing soil temperature. Furthermore, [62] mentioned that the application of biochars can reduce heat entering soils as well as heat loss which caused lower soil temperature in soils with biochars than without biochars or other similar organic amendments. Nigussie et al. [45] also found that the temperature of soils amended with biochars decreased slightly compared with those without biochars, a further confirmation that biochar carbon has a buffering effect on change in soil temperature. The results show that the combined organic amendments of fermented juices, biochar and compost can also increase soil carbon efflux or carbon mineralization by microorganisms. Abideen et al. [61] reported significant increase in soil respiration in soils with biochar and compost because the amendments stimulated beneficial microbes-soil interaction. Abideen et al. [61] also found that the application of compost-biochar mixture to soils increases the 
adsorptive soil surface for nutrients and it also stimulates microbial colonization resulting in increased soil carbon efflux.

Other studies have also revealed that soil amendments such as biochar and compost improved bacterial communities of sandy soils [44], water infiltration [63], nutrient and water retention capacity [64], and soil aeration and respiration [34]. Higa [51] and Khaliq et al. [65] reported that one of the most important effects of biochar and compost use is the promotion of soil biology. Many organisms exists within the soil ranging from large, visible organisms to organisms which can only be viewed under a powerful microscope. These organisms perform a wide range of functions, which are major contributions to what is considered normal and healthy soil [66]. It is reasonable to suggest that these organisms play essential roles in the soil ecosystem, however, their effectiveness depends on a supply of available carbon [42]. The results of our study showed that biochar and compost have a stimulation effect on the soil microbial community (bacteria, actinomycetes, and fungi) from the fermented juices as well as in the soil-born micro biota of soils. A study by [67] reported that a biochar and compost mixture increased soil microbial activities more than in chemically fertilized soils. They also noticed that microbial activity indicators, such as soil respiration, were 2.5 times greater in biochar-compost-amended soils compared with soils without such amendment, because the organic matter of compost in particular serves as food for microorganisms. Sharma et al. [68] conducted a similar experiment on the long-term effects of organic amendments such as fermented juices, biochar, and compost on soil biological activities and concluded that microbial activities were enhanced in biochar-compost-treated field plots. In their trial, soil respiration was enhanced in the organic plots compared with non-organic plots because the organic plots had higher counts of soil bacteria, actinomycetes, and fungi. Moreover, the functional diversity of soil microorganisms and their efficiency or effectiveness to metabolize organic carbon sources was increased in the organically fertilized systems with highest values recorded in the biochar-compost soils. Talaat et al. [52] and Adugna [42] concluded that two fractions of organic matter are responsible for the level of microbial activity in general: (i) easily degradable organic compounds (labile organic matter pool) may increase microbial activity and biomass, and (ii) a persistent increase of microbial biomass depends on a constant enhancement of stable organic matter which is particularly promoted by the addition of compost.

\subsection{Pepper Physiological Characteristics}

The chlorophyll content of plant leaves is a practical indicator for both potential photosynthetic productivity and general plant vigor. This is related to $\mathrm{N}$ concentration in green plants and serves as a measure of the response of crops to $\mathrm{N}$ fertilizer application and soil nutrient status [69]. The high soil $\mathrm{N}$ effect on chlorophyll content in this study was significant in that chlorophyll content was considerably higher with the inorganic fertilizer application than with the organic amendments. As expected, pepper foliar chlorophyll content was higher in the NPK plots, as the fertilizer itself contained high amounts of readily available nutrient $\mathrm{N}$ which contributed to the formation of chloroplasts and the accumulation of chlorophyll in the pepper plants [40,70]. Soil-available $\mathrm{N}$ might also have been utilized by the pepper vines to produce nucleic acids and proteins, which are essential for chlorophyll development [71]. Ghasemzadeh and Jaafar [72] opined that soils with high $\mathrm{N}$ availability can cause higher $\mathrm{N}$ uptake by the plants, as indicated by the darker green coloration of the leaves. On the contrary, even with high soil-total N, the NDVI in the NPK plots was lower than that in the fermented juices with biochar and compost-amended plots. High pepper NDVI in the fermented juices with biochar and compost plots, even under limited $\mathrm{N}$ conditions, could be attributed to improved soil bulk density and aeration, which are important contributing factors for good plant NDVI development [73]. Paulus and Anyi [38] were of the opinion that having soils with ideal bulk density is vital, as it will facilitate the pepper roots' ability to expand and scavenge for enough available nutrients and water. Although pepper growth performance is generally poor on sandy soils because 
of leaching of nutrients [49], this study revealed that gas exchange rates were higher for the NPK plots and fermented fruit juices with biochar and compost plots. According to [40], the most recommended fertilizer for pepper is the compound fertilizer, as it provides essential nutrients such as N, P, and $\mathrm{K}$ to promote better photosynthesis rates in pepper.

Sanchez et al. [41] stated that high soil $\mathrm{N}$ could be utilized by the plants and this is indicated in high photosynthetic activity, vigorous vegetative growth, and the dark green color of leaves. Nevertheless, for the soils amended with fermented juices with biochar and compost, different soil factors might have contributed to the higher pepper gas exchange rates in those plots, instead of soil-total $\mathrm{N}$ alone. McGrath and Henry [73] reported that incorporation of biochar and compost consistently decreased bulk density to below-root restricting thresholds, resulting in improved photosynthesis, stomatal conductance, and transpiration rates of plants. Furthermore, [38] mentioned that because improved bulk density enables roots to explore for water and nutrients, gas exchange rates of pepper increase and this is reflected in growth and yield. As both stomatal conductance and transpiration rates are direct indicators of plant water status [32], it was assumed that the soil porosity, which influences availability of moisture, had a significant impact on the two physiological traits of the pepper in this study. Contrary to what has been reported in the literature, soil total $\mathrm{N}$ did not affect the pepper NDVI and photosynthesis rates and this suggests that other soil factors contributed to the high photosynthetic activity in the soils with low total N. Some of these factors could be soil bulk density and porosity, because these factors significantly affect photosynthesis rates, as previously discussed. This is in agreement with [73], who stated that when soils are well drained, less compacted, and aerated, plant roots find it easier to absorb nutrients and water. Following biochar and compost application to soils, these amendments increased the plant photosynthetic rate and productivity in soils with enough available water and improved soil bulk density $[36,38,61,68]$. This observation was further confirmed by the higher stomatal conductance and transpiration rates (Table 7), as these variables are direct indicators of plant water status [32].

\subsection{Pepper Morphological Characteristics and Fresh Berry Yield}

Although the productivity of pepper on marginal soils, such as sandy soils, is poor because of their low nutrient-holding capability [28], the results in Table 5 suggest otherwise. Tanaka et al. [74] attributed the extensive loss of soil moisture in pepper farms to cleanweeding, which causes periodical removal of the soil organic layer in the pepper farms. This predicament partly explains the significant reduction of pepper fruit spike length and fresh berry yield for the treatments with NPK fertilizer and fermented juices only (Figures 6 and 8). Although the highest LAI of the pepper resulted from the NPK-fertilized plots (Figure 7), the inability of the soils to hold moisture is a concern as the soil-available water is likely to percolate downward through the soil profile into the spodic horizon or be lost through surface runoff. In a similar study, [49] reported that maintaining an ample supply of organic $C$ is crucial for sustaining soil moisture retention in sandy soils.

The positive effects of introducing fermented juices with biochar and compost on the yield of pepper, especially in the second year of this study, were consistent with our hypothesis that application of organic amendments can improve fresh berry yield of pepper. The lower pepper yields of FPJBC and FFJBC in the first year were similar to the finding of [60], who also observed that crop yield after biochar and compost application were mostly lower compared with that with mineral fertilizers, especially in the first year of application of the afore-stated organic amendments. This can be further explained by the slow release of nutrients, especially, N, P, and $\mathrm{K}$, during mineralization of the biochar and composts. The positive effects of biochar and composts on the physical, chemical, and biological properties of soils, especially sandy soils, and plant productivities should not, however, be discounted $[46,47,75]$. Long-term field trials have suggested that incorporating biochar and composts into soils equalizes the effects of annual/seasonal fluctuations with regard to water, air, and heat balance of the soils as well as improves the availability of plant nutrients and crop yield [64,76,77]. Agegnehu et al. [46] attributed yield improvement to the 
improved nutrient and water-retention capacity with biochar and compost amendments, although other mechanisms cannot be discounted. In a similar study, [62] reported that the yield increase recorded in plants grown in biochar and compost-amended soils could be associated with increase in soil $\mathrm{pH}$ which, in essence, results in higher availability of nutrients such as $\mathrm{Ca}, \mathrm{Mg}, \mathrm{K}, \mathrm{Na}$, and P. Moreover, [52] stated that through the actions of some beneficial microbes such as $\mathrm{P}$ and $\mathrm{K}$ solubilizers, biochar and compost increased the available form of nutrients for optimum uptake by plants.

Generally, the results of this study suggest that the fermented juices with biochar and compost have better effects on the yield performance of pepper grown on the Miri series (sandy soil). Mensah and Frimpong [62] also showed that biochar can be a useful amendment in improving crop yield in dry, nutrient-poor, and acidic soils. They concluded that organic amendments application is, therefore, crucial in farming systems, considering that approximately $30 \%$ of the world's soils are acidic, with more than $50 \%$ being arable lands.

\section{Conclusions}

The combined use of fermented juices with biochar and compost in mature pepper vines cultivation on sandy soils improved the physical (bulk density and porosity), chemical (pH, EC, CEC, TOC, C/N ratio, exchangeable $\mathrm{K}$, and exchangeable $\mathrm{Ca}$ ), and biological (soil temperature, soil respiration, and soil microorganism count such as bacteria, actinomycetes, and fungi) properties. Strong positive relationships were also found between soil respiration and soil microorganisms (bacteria, actinomycetes, and fungi) counts. The fermented juices with biochar and compost showed favorable results for NDVI and gas exchange rates, such as photosynthesis, stomatal conductance, and transpiration. Only pepper foliar chlorophyll and soil-total $\mathrm{N}$ were positively related, that is, foliar chlorophyll concentration increased with increasing soil total $\mathrm{N}$. There were weak relationships between soil total $\mathrm{N}$ and the pepper vines' NDVI or photosynthesis rate. The fermented juices with biochar and compost improved pepper fruit spike length and fresh berry yield relative to the existing practice of using NPK fertilizers. The findings show that these soil amendments produced from agro-wastes are a good alternative to the use of chemical fertilizers on sandy soils to improve soil fertility and productivity, and the yield of black pepper sustainably.

Author Contributions: K.M.T.S. was responsible for the investigation and original draft preparation. K.M.T.S., O.H.A., C.Y.K.; P.S.L. and M.B.J. conceived and designed the experiments, data analysis and preparation of the manuscript for publication. O.H.A. was responsible for supervising, funding acquisition, project administration, editing and reviewing. J.A.M.Z. and M.B.J. involved in funding acquisition, resources and project administration. A.A.M., A.A. (Azwan Awang) and A.A. (Arifin $\mathrm{Abdu}$ ) were involved in data visualization, data curation, reviewing and editing the draft at different stages. All authors have read and agreed to the published version of the manuscript.

Funding: This research was funded by the Fundamental Research Grant Scheme (FRGS), with grant codes FRGS/2/2013/STWN03/UPM/02/6 and FRG0301-STWN-1/2011, of the Ministry of Higher Education, Malaysia.

Institutional Review Board Statement: Not applicable.

Informed Consent Statement: Not applicable.

Data Availability Statement: Not applicable.

Acknowledgments: The authors would like to acknowledge the Ministry of Higher Education, Malaysia for funding this research project through the Fundamental Research Grant Scheme (FRGS) with grant codes FRGS/2/2013/STWN03/UPM/02/6 and FRG0301-STWN-1/2011. The authors also acknowledge colleagues and staff at Universiti Putra Malaysia Bintulu Sarawak Campus, Malaysia Pepper Board, Kuching, Sarawak and Universiti Malaysia Sabah, Sandakan Branch for their technical support and cooperation.

Conflicts of Interest: The authors declare no conflict of interest. 


\section{References}

1. Han, C.; Chen, S.; Yu, Y.; Xu, Z.; Zhu, B.; Xu, X.; Wang, Z. Evaluation of Agricultural Land Suitability Based on RS, AHP, and MEA: A Case Study in Jilin Province, China. Agriculture 2021, 11, 370. [CrossRef]

2. Eswaran, H.; Vearasilp, T.; Reich, P.; Beinroth, F. Sandy soils of Asia: A new frontier for agricultural development? In A Holistic Approach for Sustainable Development of Problem Soils in the Tropics, Proceedings of the Management of Tropical Sandy Soils for Sustainable Agriculture, Khon Kaen, Thailand, 27 November-2 December 2005; FAO: Bangkok, Thailand, 2005; pp. 22-30.

3. De Jesus Duarte, S.; Glaser, B.; Paiva de Lima, R.; Pelegrino Cerri, C.E. Chemical, Physical, and Hydraulic Properties as Affected by One Year of Miscanthus Biochar Interaction with Sandy and Loamy Tropical Soils. Soil Syst. 2019, 3, 24. [CrossRef]

4. Sassenrath, G.F.; Davis, K.; Sassenrath-Cole, A.; Riding, N. Exploring the Physical, Chemical and Biological Components of Soil: Improving Soil Health for Better Productive Capacity. Kans. Agric. Exp. Stn. Res. Rep. 2018, 4, 16. [CrossRef]

5. Abdul Khalil, H.P.S.; Hossain, M.S.; Rosamah, E.; Azli, N.A.; Saddon, N.; Davoudpoura, Y.; Islam, M.N.; Dungani, R. The role of soil properties and it's interaction towards quality plant fiber: A review. Renew. Sustain. Energy Rev. 2015, 43, 1006-1015. [CrossRef]

6. Tahat, M.M.; Alananbeh, K.; Othman, Y.A.; Leskovar, D.I. Soil Health and Sustainable Agriculture. Sustainability 2020, $12,4859$. [CrossRef]

7. Gill, S.; Alshankiti, A.; Shahid, S.; Rodriguez, J.P. Amending Soil Health to Improve Productivity of Alternate Crops in Marginal Sandy Soils of the UAE. In Emerging Research in Alternative Crops; Springer Nature: Cham, Switzerland, 2020; pp. 93-124. [CrossRef]

8. Oueriemmi, H.; Kidd, P.S.; Trasar-Cepeda, C.; Rodríguez-Garrido, B.; Zoghlami, R.I.; Ardhaoui, K.; Prieto-Fernández, Á.; Moussa, M. Evaluation of Composted Organic Wastes and Farmyard Manure for Improving Fertility of Poor Sandy Soils in Arid Regions. Agriculture 2021, 11, 415. [CrossRef]

9. Manickam, T.; Cornelissen, G.; Bachmann, R.T.; Ibrahim, I.Z.; Mulder, J.; Hale, S.E. Biochar Application in Malaysian Sandy and Acid Sulfate Soils: Soil Amelioration Effects and Improved Crop Production over Two Cropping Seasons. Sustainability 2015, 7 , 16756-16770. [CrossRef]

10. Chatzistathis, T.; Tzanakakis, V.; Giannakoula, A.; Psoma, P. Inorganic and Organic Amendments Affect Soil Fertility, Nutrition, Photosystem II Activity, and Fruit Weight and May Enhance the Sustainability of Solanum lycopersicon L. (Cv. 'Mountain Fresh') Crop. Sustainability 2020, 12, 9028. [CrossRef]

11. Chandini, K.R.; Kumar, R.; Prakash, O. The Impact of Chemical Fertilizers on Our Environment and Ecosystem. In Research Trends in Environmental Sciences; AkiNik Publications: New Delhi, India, 2019; pp. 69-86.

12. Martínez-Dalmau, J.; Berbel, J.; Ordóñez-Fernández, R. Nitrogen Fertilization. A Review of the Risks Associated with the Inefficiency of Its Use and Policy Responses. Sustainability 2021, 13, 5625. [CrossRef]

13. Mahmud, K.; Panday, D.; Mergoum, A.; Missaoui, A. Nitrogen Losses and Potential Mitigation Strategies for a Sustainable Agroecosystem. Sustainability 2021, 13, 2400. [CrossRef]

14. Rahaman, M.A.; Zhan, X.; Zhang, Q.; Li, S.; Lv, S.; Long, Y.; Zeng, H. Ammonia Volatilization Reduced by Combined Application of Biogas Slurry and Chemical Fertilizer in Maize-Wheat Rotation System in North China Plain. Sustainability 2020, 12, 4400. [CrossRef]

15. Rahman, K.M.A.; Zhang, D. Effects of Fertilizer Broadcasting on the Excessive Use of Inorganic Fertilizers and Environmental Sustainability. Sustainability 2018, 10, 759. [CrossRef]

16. Wu, L.; Jiang, Y.; Zhao, F.; He, X.; Liu, H.; Yu, K. Increased organic fertilizer application and reduced chemical fertilizer application affect the soil properties and bacterial communities of grape rhizosphere soil. Sci. Rep. 2020, 10, 9568. [CrossRef]

17. Liu, Z.; Xie, W.; Yang, Z.; Huang, X.; Zhou, H. Effects of Manure and Chemical Fertilizer on Bacterial Community Structure and Soil Enzyme Activities in North China. Agronomy 2021, 11, 1017. [CrossRef]

18. Li, Y.; Wang, C.; Wang, T.; Liu, Y.; Jia, S.; Gao, Y.; Liu, S. Effects of Different Fertilizer Treatments on Rhizosphere Soil Microbiome Composition and Functions. Land 2020, 9, 329. [CrossRef]

19. Tang, A.; Haruna, A.O.; Majid, N.M.A.; Jalloh, M.B. Effects of Selected Functional Bacteria on Maize Growth and Nutrient Use Efficiency. Microorganisms 2020, 8, 854. [CrossRef] [PubMed]

20. Zhao, Y.; Chen, Y.; Dai, H.; Cui, J.; Wang, L.; Sui, P. Effects of Organic Amendments on the Improvement of Soil Nutrients and Crop Yield in Sandy Soils during a 4-Year Field Experiment in Huang-Huai-Hai Plain, Northern China. Agronomy 2021, 11, 157. [CrossRef]

21. Doan, T.T.; Sisouvanh, P.; Sengkhrua, T.; Sritumboon, S.; Rumpel, C.; Jouquet, P.; Bottinelli, N. Site-Specific Effects of Organic Amendments on Parameters of Tropical Agricultural Soil and Yield: A Field Experiment in Three Countries in Southeast Asia. Agronomy 2021, 11, 348. [CrossRef]

22. The Borneo Post. Available online: https://www.theborneopost.com/2018/11/29/farmers-struggle-with-low-prices/ (accessed on 17 August 2021).

23. Soil Survey Staff. Kellogg Soil Survey Laboratory Methods Manual; Soil Survey Investigations Report No. 42, Version 5.0; Burt, R., Soil Survey Staff, Eds.; U.S. Department of Agriculture, Natural Resources Conservation Service: Lincoln, NE, USA, 2014; pp. 279-281.

24. Paramananthan, S. Soils of Malaysia: Their Characteristics and Identification. Volume 1; Academy of Sciences Malaysia \& Param Agricultural Soil Surveys: Selangor, Malaysia, 2000; pp. 121-125. 
25. Zamora, O.B.; Calub, B.M. Organic Agriculture Technologies and Systems Developed and Adapted by Farmers in the Phillippines; Department of Agriculture-Bureau of Agricultural Research and University of Philippines: Los Banos-College of Agriculture: Quezon City, Phillippines, 2016; p. 70. ISBN 978-971-0347-46-9.

26. Malaysian Pepper Board. Laporan Kajian Verifikasi Hasil; Malaysian Pepper Board: Kuching, Malaysia, $2017 ;$ p. 11.

27. Sulok, K.M.T.; Ahmed, O.H.; Khew, C.Y.; Zehnder, J.A.M.; Jalloh, M.B.; Musah, A.A.; Abdu, A. Chemical and Biological Characteristics of Organic Amendments Produced from Selected Agro-Wastes with Potential for Sustaining Soil Health: A Laboratory Assessment. Sustainability 2021, 13, 4919. [CrossRef]

28. Paulus, A.D. Planting and Maintenance. In Pepper Production Technology in Malaysia; Lai, K.F., Sim, S.L., Eds.; Malaysian Pepper Board: Kuching, Malaysia, 2011; pp. 106-109.

29. Tan, K.H. Soil Sampling, Preparation, and Analysis, 2nd ed.; CRC Press: Boca Raton, FL, USA, 2005.

30. Cottenie, A. Soil testing and plant testing as a basis of fertilizer recommendation. FAO Soils Bull. 1980, 38, 70-73.

31. Bremner, J.M. Total Nitrogen. In Methods of Soil Analysis, Part 2; Black, C.A., Evans, D.D., Ensminger, L.E., White, J.L., Clark, F.F., Dinauer, R.C., Eds.; American Society of Agronomy: Madison, WI, USA, 1965; pp. 1149-1178.

32. DiCristina, K.; Germino, M. Correlation of neighborhood relationships, carbon assimilation, and water status of Sagebrush seedlings establishing after fire. West. N. Am. Nat. 2006, 66, 441-449. [CrossRef]

33. Bianco, S.; Pitelli, R.; Bianco, M. Estimate of Brachiaria Plantaginea Leaf Area Using Linear Dimensions of the Leaf Blade. Planta Daninha 2005, 23, 597-601. [CrossRef]

34. International Biochar Initiative. Standardized Product Definition and Product Testing Guidelines for Biochar That Is Used in Soil; IBI-STD-2.1; International Biochar Initiative: New York, NY, USA, 2015; p. 47.

35. Javaid, A.; Bajwa, R. Field Evaluation of Effective Microorganisms (EM) Application for Growth, Nodulation, and Nutrition of Mungbean. Turk. J. Agric. For. 2011, 35, 443-452. [CrossRef]

36. Schulz, H.; Glaser, B. Effects of biochar compared to organic and inorganic fertilizers on soil quality and plant growth in a greenhouse experiment. J. Plant Nutr. Soil Sci. 2012, 175, 410-422. [CrossRef]

37. Wahi, R.; Sharifah Mona, A.A.; Sinin, H.; Zainab, N. Biochar production from agricultural wastes via low-temperature microwave carbonization. In Proceedings of the 2015 IEEE International RF and Microwave Conference (RFM 2015), Kuching, Malaysia, 14-16 December 2015. [CrossRef]

38. Paulus, A.D.; Anyi, W.L. Introduction. In Pepper Production Technology in Malaysia; Lai, K.F., Sim, S.L., Eds.; Malaysian Pepper Board: Kuching, Malaysia, 2011; pp. 3-4.

39. Tedersoo, L.; Smith, M.E. Lineages of ectomycorrhizal fungi revisited: Foraging strategies and novel lineages revealed by sequences from belowground. Fungal Biol. Rev. 2013, 27, 83-99. [CrossRef]

40. Yap, C.A. Determination of nutrient uptake characteristics of black pepper (Piper nigrum L.). J. Agric. Sci. Technol. 2012, 6, 86-89.

41. Sanchez, J.E.; Willson, T.C.; Kizilkaya, K.; Parker, E.; Harwood, R.R. Enhancing the Mineralizable Nitrogen Pool Through Substrate Diversity in Long Term Cropping Systems. Soil Sci. Soc. Am. J. SSAJ 2001, 65, 1442-1447. [CrossRef]

42. Adugna, G. A review on impact of compost on soil properties, water use and crop productivity. Acad. Res. J. Agric. Sci. Res. 2016, 4, 93-104.

43. Lehmann, J.; Gaunt, J.; Rondon, M.B. Bio-char Sequestration in Terrestrial Ecosystems-A Review. Mitig. Adapt. Strat. Glob. Change 2006, 11, 403-427. [CrossRef]

44. Fischer, D.; Glaser, B. Synergisms between compost and biochar for sustainable soil amelioration, management of organic Waste. In Management of Organic Waste/Synergism between Biochar and Compost for Sustainable Soil Amelioration; Kumar, S.E., Ed.; InTechOpen: Shanghai, China, 2012; pp. 167-198. Available online: https://www.intechopen.com/books/management-oforganic-waste/synergism-between-biochar-and-compost-for-sustainable-soil-amelioration (accessed on 12 June 2021).

45. Nigussie, A.; Kissi, E.; Misganaw, M.; Ambaw, G. Effect of biochar application on soil properties and nutrient uptake of let-tuces (Lactuca sativa) grown in chromium polluted soils. Am. Eurasian J. Agric. Environ. Sci. 2012, 12, 369-376.

46. Agegnehu, G.; Nelson, P.N.; Bird, M.I. Crop yield, plant nutrient uptake and soil physicochemical properties under organic soil amendments and nitrogen fertilization on Nitisols. Soil Tillage Res. 2016, 160, 1-13. [CrossRef]

47. Amlinger, F.; Peyr, S.; Geszti, J.; Dreher, P.; Karlheinz, W.; Nortcliff, S. Beneficial Effects of Compost Application on Fertility and Productivity of Soils. Literature Study; Federal Ministry for Agriculture and Forestry, Environment and Water Management: Vienna, Austria, 2007; 225p.

48. Subler, S.; Edwards, C.A.; Metzger, J. Comparing vermicomposts and composts. Biocycle 1998, 39, 63-66.

49. Ho, S.Y.; Wasli, M.E.B.; Perumal, M. Evaluation of Physicochemical Properties of Sandy-Textured Soils under Smallholder Agricultural Land Use Practices in Sarawak, East Malaysia. Appl. Environ. Soil Sci. 2019, 2019, e7685451. [CrossRef]

50. Wong, T.H. Agronomic recommendations for pepper cultivation in Sarawak. In Proceedings of the National Conference on Pepper in Malaysia; Bong, C.F.J., Saad, M.S., Eds.; Universiti Pertanian Malaysia: Bintulu, Malaysia, 1986; pp. 96-103.

51. Higa, T. Effective microorganisms and their role in Kyusei nature farming and sustainable agriculture. In Proceedings of the 2nd Conference on Effective Microorganisms, Kyusei Nature Farming Center, Saraburi, Thailand, 17-19 November 1993; pp. 1-6.

52. Talaat, N.B.; Ghoniem, A.E.; Abdelhamid, M.T.; Shawky, B.T. Effective microorganisms improve growth performance, alter nutrient acquisition and induce compatible solutes accumulation in common bean (Phaseolus vulgaris L.) plants subjected to salinity stress. Plant Growth Regul. 2015, 75, 281-295. [CrossRef] 
53. Doran, J.W.; Zeiss, M.R. Soil health and sustainability: Managing the biotic component of soil quality. Appl. Soil Ecol. 2000, 15, 3-11. [CrossRef]

54. Rajkovich, S.; Enders, A.; Hanley, K.; Hyland, C.; Zimmerman, A.R.; Lehmann, J. Corn growth and nitrogen nutrition after additions of biochars with varying properties to a temperate soil. Biol. Fertil. Soils 2012, 48, 271-284. [CrossRef]

55. Suhaimee, S.; Ibrahim, I.Z.; Abdul Wahab, M.A.M. Organic Agriculture in Malaysia; FFTC Agricultural Policy Articles: Production Policy: Taipei, Taiwan, 2016; Available online: http:/ /ap.fftc.agnet.org/ap_db.php?id=579 (accessed on 12 June 2021).

56. Zimmermann, I. Trial with Charcoal as a Soil Amendment for Growing Lucerne; Polytechnic of Namibia: Windhoek, Namibia, 2008; unpublished report.

57. Kim, J.-S.; Sparovek, G.; Longo, R.M.; de Melo, W.J.; Crowley, D. Bacterial diversity of terra preta and pristine forest soil from the Western Amazon. Soil Biol. Biochem. 2007, 39, 684-690. [CrossRef]

58. Sun, P.-F.; Fang, W.-T.; Shin, L.-Y.; Wei, J.-Y.; Fu, S.-F.; Chou, J.-Y. Indole-3-Acetic Acid-Producing Yeasts in the Phyllosphere of the Carnivorous Plant Drosera indica L. PLoS ONE 2014, 9, e114196. [CrossRef]

59. Saeid, A.; Prochownik, E.; Dobrowolska-Iwanek, J. Phosphorus Solubilization by Bacillus Species. Molecules 2018, $23,2897$. [CrossRef]

60. Agegnehu, G.; Bass, A.M.; Nelson, P.N.; Muirhead, B.; Wright, G.; Bird, M.I. Biochar and biochar-compost as soil amendments: Effects on peanut yield, soil properties and greenhouse gas emissions in tropical North Queensland, Australia. Agric. Ecosyst. Environ. 2015, 213, 72-85. [CrossRef]

61. Abideen, Z.; Koyro, H.-W.; Huchzermeyer, B.; Gul, B.; Khan, M.A. Impact of a biochar or a compost-biochar mixture on water relation, nutrient uptake and photosynthesis of Phragmites karka. Pedosphere 2017, 30, 466-477. [CrossRef]

62. Mensah, A.K.; Frimpong, K.A. Biochar and/or Compost Applications Improve Soil Properties, Growth, and Yield of Maize Grown in Acidic Rainforest and Coastal Savannah Soils in Ghana. Int. J. Agron. 2018, 2018, e6837404. [CrossRef]

63. Glaser, B.; Haumaier, L.; Guggenberger, G.; Zech, W. The 'Terra Preta' phenomenon: A model for sustainable agriculture in the humid tropics. Naturwissneschaften 2001, 88, 37-41. [CrossRef] [PubMed]

64. Hunt, J.; DuPonte, M.; Sato, D.; Kawabata, A. The basics of Biochar: A Natural Soil Amendment. Soil Crop Manag. 2010, 30, 1-4.

65. Khaliq, A.; Abbasi, M.K.; Hussain, T. Effects of integrated use of organic and inorganic nutrient sources with effective microorganisms (EM) on seed cotton yield in Pakistan. Bioresour. Technol. 2016, 97, 967-972. [CrossRef] [PubMed]

66. Megir, G.; Paulus, A.D. Organic Pepper Production. In Pepper Production Technology in Malaysia; Lai, K.F., Sim, S.L., Eds.; Malaysian Pepper Board: Kuching, Malaysia, 2011; pp. 229-233.

67. Partanen, P.; Hultman, J.; Paulin, L.; Auvinen, P.; Romantschuk, M. Bacterial diversity at different stages of the composting process. BMC Microbiol. 2010, 10, 94. [CrossRef] [PubMed]

68. Sharma, A.; Saha, N.T.; Arora, A.; Shah, R.; Nain, L. Efficient microorganism compost benefits plant growth and improves soil health in Calendula and Marigold. Hortic. Plant J. 2017, 3, 67-72. [CrossRef]

69. Sattelmacher, B.; Horst, W.J.; Becker, H.C. Factors that contribute to genetic variation for nutrient efficiency of crop plants. Zeitschrift für Pflanzenernährung und Bodenkunde 1994, 157, 215-224. [CrossRef]

70. Miller, S.A.; Ikeda, D.M.; Weinert, E., Jr.; Chang, K.; McGinn, J.M.; Keliihoomalu, C.; Duponte, M.W. Natural Farming: Fermented Plant Juice; Sustainable Agriculture, SA-7; Universiti of Hawaii, College of Tropical Agriculture and Human Resources: Honolulu, HI, USA, 2013; p. 6.

71. Huerta-Pujol, O.; Soliva, M.; Martinez-Farre, F.X.; Valero, J.; Lopez, M. Bulk density determination as a simple and complementary too in composting process control. Bioresour. Technol. 2010, 101, 995-1001. [CrossRef] [PubMed]

72. Ghasemzadeh, A.; Jaafar, H.Z.E. Effect of $\mathrm{CO}_{2}$ Enrichment on Synthesis of Some Primary and Secondary Metabolites in Ginger (Zingiber officinale Roscoe). Int. J. Mol. Sci. 2011, 12, 1101-1114. [CrossRef]

73. McGrath, D.; Henry, J. Organic amendments decrease bulk density and improve tree establishment and growth in roadside plantings. Urban For. Urban Green. 2016, 20, 120-127. [CrossRef]

74. Tanaka, S.; Tachibe, S.; Wasli, M.E.; Lat, J.; Seman, L.; Kendawang, J.J.; Iwasaki, K.; Sakurai, K. Soil characteristics under cash crop farming in upland areas of Sarawak, Malaysia. Agric. Ecosyst. Environ. 2009, 129, 293-301. [CrossRef]

75. Thies, J.E.; Rillig, M.C. Characteristics of biochar: Biological properties. In Biochar for Environmental Management: Science and Technology, 1st ed.; Lehmann, J., Joseph, S., Eds.; Earthscan Publications Ltd.: London, UK, 2009; pp. 85-105.

76. Atiyeh, R.M.; Subler, S.; Edwards, C.A.; Metzger, J. Growth of tomato plants in horticultural potting media amended with vermicomposts. Pedobiologia 2000, 43, 724-728.

77. Clark, K.M.; Boardman, D.L.; Staples, J.S.; Easterby, S.; Reinbott, T.M.; Kremer, R.J.; Kitchen, N.R.; Veum, K.S. Crop Yield and Soil Organic Carbon in Conventional and No-till Organic Systems on a Claypan Soil. Agron. J. 2017, 109, 588-599. [CrossRef] 